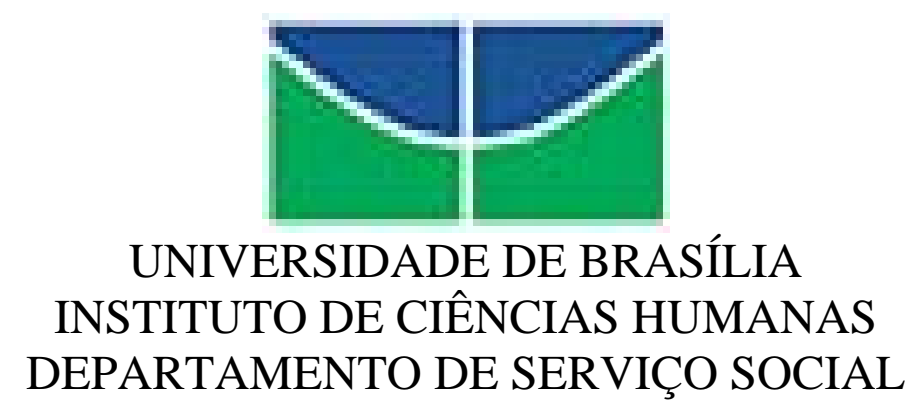

CONCEITOS, MARCOS LEGAIS E ANÁLISES DO DISQUE DENÚNCIA NACIONAL DE ABUSO E EXPLORAÇÃO SEXUAL DE CRIANÇAS E ADOLESCENTES

TRABALHO DE CONCLUSÃO DE CURSO

André Luiz Cerqueira

Matrícula: 03/72960 


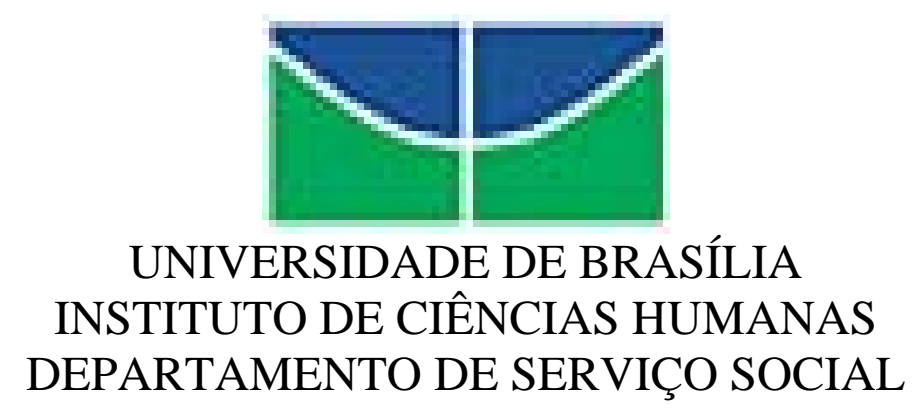

CONCEITOS, MARCOS LEGAIS E ANÁLISES DO DISQUE DENÚNCIA NACIONAL DE ABUSO E EXPLORAÇÃO SEXUAL DE CRIANÇAS E ADOLESCENTES

Trabalho de Conclusão de Curso apresentado como requisito para a aquisição do grau de Assistente Social no curso de Serviço Social da Universidade de Brasília.

Orientadora: Doutora Maria Lúcia Pinto Leal 


\section{CONCEITOS, MARCOS LEGAIS DO DISQUE DENÚNCIA NACIONAL DE ABUSO E EXPLORAÇÃO SEXUAL DE CRIANÇAS E ADOLESCENTES}

Trabalho defendido sob avaliação da Banca Examinadora constituída por:

Prof $^{a}$. Doutora Maria Lúcia Pinto Leal (Orientadora)

Universidade de Brasília

Prof. Doutor Mario Ângelo Silva

Universidade de Brasília

Prof ${ }^{\mathrm{a}}$. Mestre Patrícia Cristina Pinheiro de Almeida

Universidade de Brasília 


\section{Agradecimentos}

Mostro-me grato:

às instituições que possibilitaram os estudos de campos abertamente, fornecendo profissionais para entrevista;

à Priscila Martins pelo apoio e pelas construtivas discussões a respeito da pesquisa científica;

à Cristina Silva pelas sugestões e críticas na fase final deste estudo; e

à professora Maria Lúcia Pinto Leal pelo conhecimento compartilhado, pela paciência e atenção na pesquisa e dedicação nessa construção que veio a solidificar o pesquisador em sua formação em Serviço Social. 


\section{Sumário}

Resumo

Páginas

Pa....07

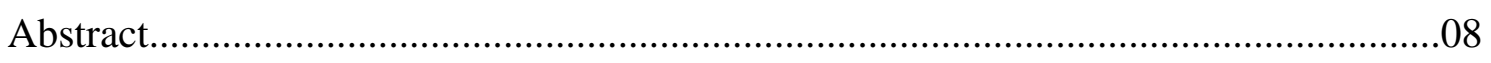

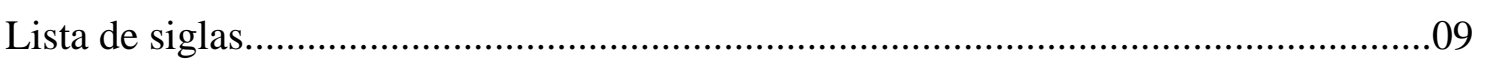

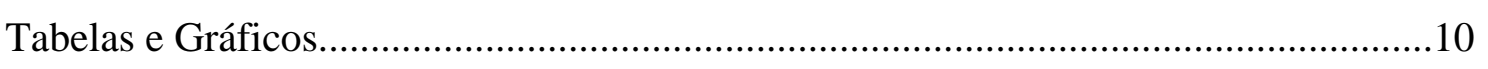

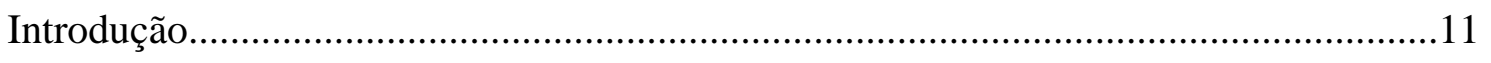

1. Abordagem teórico-metodológica...........................................................................

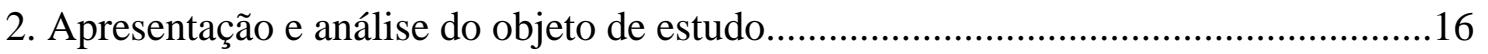

2.1. Conceitos referentes à Exploração Sexual Contra Crianças e Adolescentes.............16

2.2. Marco Legal Internacional e Nacional Referente à Exploração dos Direitos de

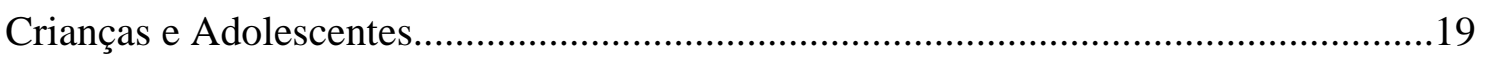

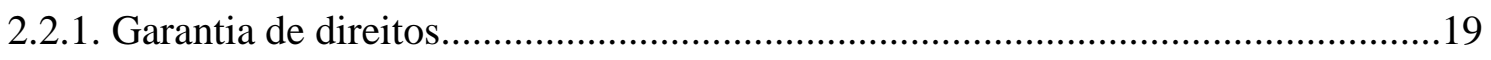

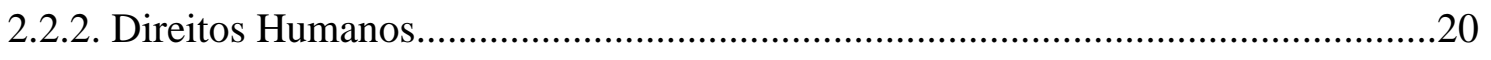

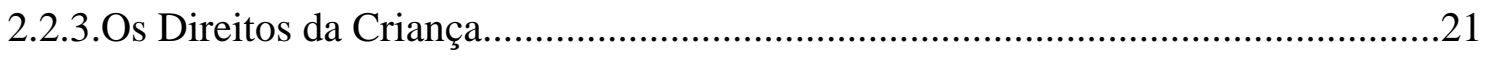

2.2.4. A Convenção Internacional sobre o Direito da Criança 1989...............................22

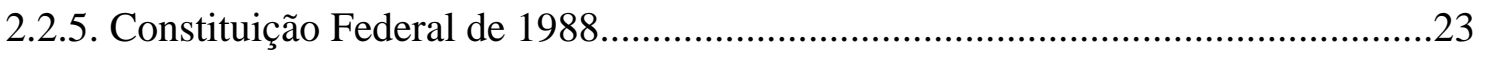

2.2.6. Internalização dos tratados e convenções assinados pelo Estado brasileiro...........24

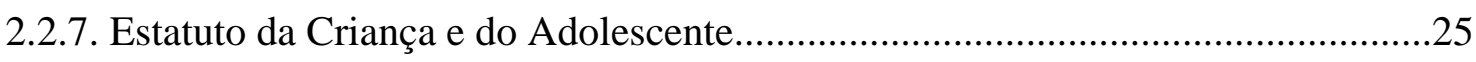

2.2.7.1. Princípios do Estatuto da Criança e do Adolescente..........................................26

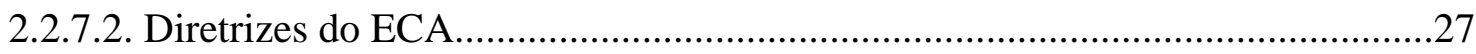

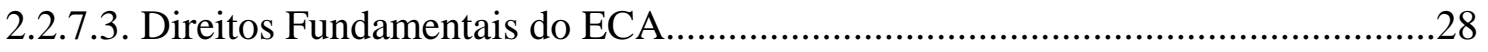

2.2.7.4. Avanços do Estatuto em face a legislação anterior revogada.............................28

2.3. Serviço Disque Denúncia Nacional de Abuso e Exploração Sexual de Crianças e

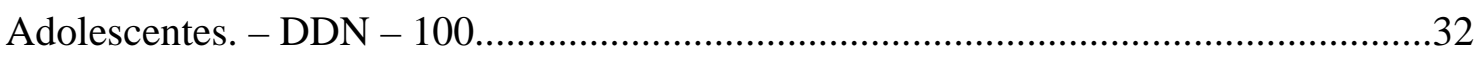

2.3.1. Histórico do Serviço.............................................................................................33

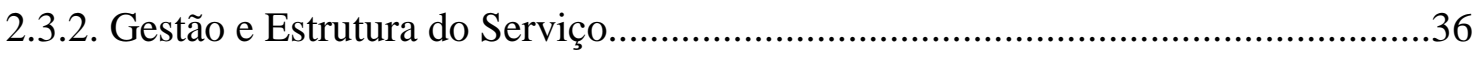

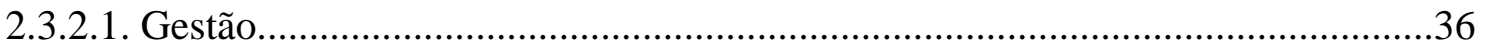

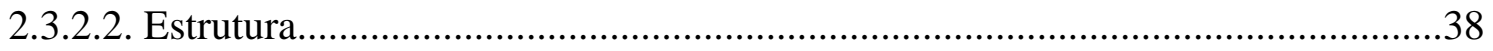

2.3.2.2.1. Nível 1 - Teleatendimento..........................................................................38

2.3.2.2.2. Nível 2 - Análise e Encaminhamento da Denúncia......................................40 
2.3.2.2.3. Nível 3 - Análise e tratamento de dados........................................................44

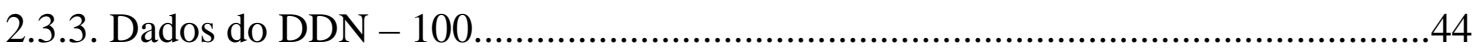

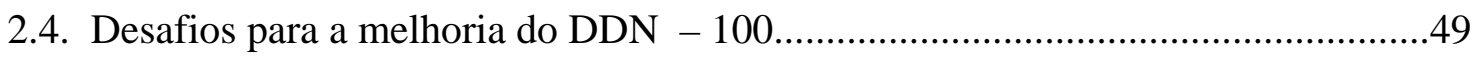

2.4.1. Melhoria da articulação com os órgãos de responsabilização e defesa................49

2.4.2. Melhoria do tratamento da base de dados........................................................50

2.4.3. Estabelecimento de estratégias sistemáticas de divulgação dos dados.................50

2.4.4. Garantia de recursos orçamentários oriundos da Fonte do Tesouro, com vistas à

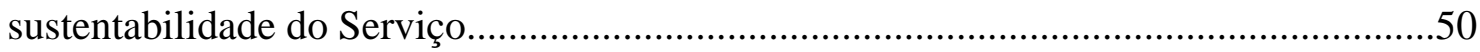

2.4.5. Implantação do sistema de encaminhamento on-line em todas as Unidades da

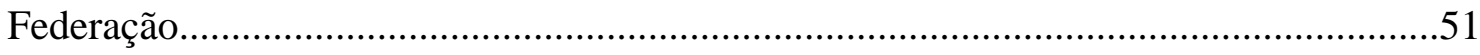

2.4.6. Integração aos demais canais de denúncia (serviços estaduais)..........................52

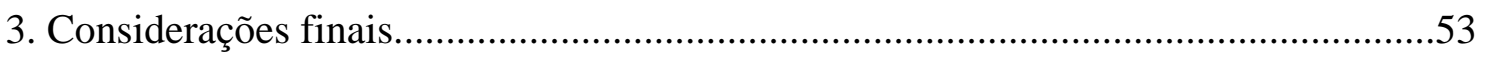

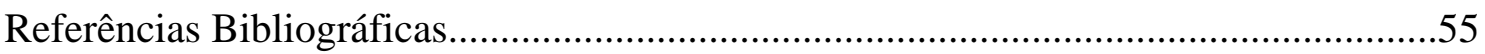

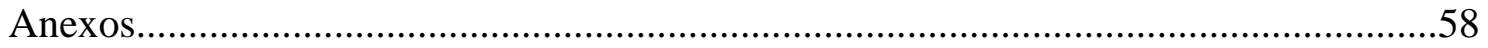




\section{Resumo}

Essa monografia buscou identificar os conceitos que envolvem e circulam o abuso e a exploração sexual de crianças e adolescentes, conceitos vistos sobre diversas visões de autores consagrados na área debatida. Trata também do marco legal nacional e internacional que envolve os direitos da criança e adolescente, destacando as principais legislações referentes à temática. O estudo analisa o Serviço Disque Denúncia de Abuso e Exploração Sexual Contra Crianças e Adolescentes (DDN-100), que será estudado em sua total complexidade levando em conta os aspectos institucionais, de gestão, organização, fluxos da denúncia, operacionalização, base de dados, dentre outros.

Palavras-chave: Violência Sexual. Marco Legal. DDN-100. 


\begin{abstract}
This paper has searched to identify the concepts involving sexual abuse and exploitation of children and teenagers, taking into account concepts from many authors with different perspectives on the debated area. It also presents the national and international legal framework involving children rights, pointing out the most important legislation on the issue. This paper uses the call center service for sexual abuse and exploitation of children in Brazil (Disque Denúncia de Abuso e Exploração Sexual de Crianças e Adolescentes - (DDN 100), which will be studied in its total complexity taking into consideration the institutional, political, administrative, organizational, denunciation lines, operational, database and others aspects. This will lead to a more comprehensive and critic understanding of the service, questioning the visibility and social control of the DDN-100.
\end{abstract}

Keywords: Sexual Violence. Legal Framework. DDN-100. 


\section{Lista de Siglas}

Abrapia - Associação Brasileira Multiprofissional de proteção à infância e à adolescência.

ANDI - Agência de Notícias dos Direitos da Infância.

CF - Constituição Federal de 1988.

Cecria - Centro de Referência, Estudos e Ações sobre Crianças e Adolescentes.

DDG - Discagem Direta Gratuita.

DDN-100 - Serviço Disque Denúncia Nacional de Abuso e Exploração Sexual de Crianças e Adolescentes.

ECA - Estatuto da Criança e do Adolescente.

Embratur - Empresa Brasileira de Turismo.

ONU - Organização das Nações Unidas.

Petrobras - Petróleo Brasileiro S.A.

PR - Presidência da República.

ReDesap - Rede Nacional de Identificação e Localização de Crianças e Adolescentes Desaparecido.

SBT - Sistema Brasileiro de Televisão.

SEDH - Secretaria Especial dos Direitos Humanos.

UNICEF - Fundo das Nações Unidas para a Infância.

SPDCA - Subsecretaria de Proteção aos Direitos da Criança e do Adolescente.

SUS - Sistema Único de Saúde. 


\section{Tabelas e Gráficos}

\section{$\underline{\text { Tabelas }}$}

Tabela 1. Sistematização das Principais Diferenças entra ECA e Código de Menores.

Tabela 2. Base Legal de Encaminhamentos aos Principais Órgãos Receptores de Denúncias.

Tabela 3. Encaminhamento e Acompanhamento on-line das Denúncias.

Tabela 4. Total de Atendimentos Recebidos pelos Teleatendentes no Período de 21/02/2005 à 11/03/2006.

Tabela 5. Total de denúncias por categorias.

Tabela 6. Registros dos Tipos de Violência nas Denúncias categorizadas de 2003 a 20 de março de 2007.

\section{Gráficos}

Gráfico 1. Evolução das Denúncias - maio 2006

Gráfico 2. Disque Denúncia - 100 Total de Denúncias Brasil por ano

Gráfico 3. Disque Denúncia - 100 Registros por Categoria de Violência Brasil 2003 a 20 de março de 2007 


\section{Introdução}

Exploração sexual no Brasil configura-se como uma forma de extrema violação de direitos contra o ser humano. Quando esse tipo de violência relaciona-se ao universo da criança e do adolescente, o tema, além de prioritário, passa a configurar o mais desafiante e contundente da agenda social do país, exigindo do Poder Público e da sociedade um esforço conjunto de enfrentamento e coibição de sua prática.

A superação dessa iniqüidade foi preconizada nos Congressos Mundiais de Estocolmo (Suécia) e de Yokohama (Japão), na Constituição Brasileira de 1988, na Convenção Internacional sobre os Direitos da Criança de 1989 e na lei 8069/90 - que promulga o Estatuto da Criança e do Adolescente - ECA e é pauta nas discussões da sociedade civil há alguns anos. Por parte do Governo Federal, no entanto, só foi considerada prioridade a partir de 2003, quando a Presidência da República declarou o compromisso do governo com a superação dessa grave violação de direitos sofrida pelas crianças e adolescentes do Brasil.

O Estado, ao priorizar o problema da exploração sexual contra crianças e adolescentes, tem procurado traçar estratégias competentes e fundamentadas para o enfrentamento a essa ação criminosa e violadora dos direitos essenciais das crianças e dos adolescentes (Faleiros, 1998). E nesse contexto que entra o Serviço Disque Denúncia Nacional de Abuso e Exploração Sexual de Crianças e Adolescentes (DDN100). O Disque é de responsabilidade da Secretaria Especial dos Direitos Humanos, ligada a Presidência da República, participando da co-gestão, está a frente o Cecria e a Petrobras, este somente com o financiamento do Serviço. Entender o funcionamento do DDN-100, de acordo com uma análise teórico-metodológica dialética, resgatando a historicidades dos fatos, das políticas de proteção à criança e ao adolescente, a construção histórica do Disque Denúncia a partir de demandas da sociedade civil, tudo isso é fundamental, visto que constitui um direito garantido por legislações nacionais e internacionais e por recentemente o PPA 2004/2007.

Com base em análise qualitativa do enfrentamento da violência e abuso sexual de crianças e adolescentes e verificação quantitativa dos dados fornecidos pelo Serviço Disque Denúncia que dão visibilidade à problemática, as perguntas que orientam a pesquisa serão: O que ocorre com notificações de violência e abuso sexual contra criança e adolescentes denunciadas no Serviço Disque Denúncia? Que percurso 
(circuito) essas denúncias percorrem? Que dispositivos, procedimentos e relações de poder entravam ou facilitam a resolubilidade das situações denunciadas? Que concepções vêm orientando o enfrentamento da exploração sexual? Quais são as principais legislações nacionais e internacionais que dão parâmetros à questão da violação e proteção dos direitos de crianças e adolescentes?

Hoje o Disque Denúncia já é uma referência no mapeamento quantitativo da situação brasileira no que diz respeito à violência sexual contra crianças e adolescentes. Porém, será possível que o Serviço seja suficiente para assegurar o enfrentamento da violência contra crianças e adolescentes através de notificações formalizadas?

O primeiro capítulo estabelecerá o conceito, segundo várias visões, de diversas formas de violência cometidas contra crianças e adolescentes, além das relações de poder existentes nas diferentes formas de violação dos direitos da criança e do adolescente.

Na segunda parte, realizará um estudo das principais legislações nacionais e internacionais que, de certa forma, organizam, estabelecem princípios, diretrizes com relação a violência cometidas contra crianças e adolescentes. Também neste capítulo, será possível verificar a necessidade de proteger os direitos fundamentais da criança e do adolescente. Nessa análise, destacaremos a importância das legislações nacionais (Constituição Brasileira de 1988, Estatuto da Criança e do Adolescente, este com destaque à legislação anteriormente revogada) e também com referência às legislações internacionais (Declaração sobre os Direitos da Criança, Declaração Universal dos Direitos Humanos, promulgada pela ONU em 1948, a segunda Declaração Universal dos Direitos da Criança e 1989 os países que formavam a ONU construíram a Convenção sobre o Direito da Criança).

A terceira parte deste estudo, abordará o Serviço Disque Denúncia Nacional de Abuso e Exploração Sexual de Crianças e Adolescentes (DDN-100). Nessa parte o enfoque será nos aspectos que envolvem o DDN-100, entre eles:(histórico, gestão, parceiros do programa, estrutura física para notificação das denúncias, financiamento do Serviço e os avanços e problemas enfrentados em todo o processo).

Segue o último capítulo, Considerações Finais, no qual estão as principais conclusões da pesquisa. Espera-se que os resultados possibilitem uma compreensão crítica da temática abordada. Que contribuam para entender o DDN-100, através do suporte teórico referente ao enfrentamento da violência e abuso sexual contra crianças e adolescentes e revendo as legislações que circulam essa temática, analisando o Serviço 
Disque Denúncia Nacional de Abuso e Exploração Sexual de Crianças e Adolescentes e entendendo o funcionamento do mesmo em sua total complexidade. A parti deste Estudo, será possível responder as principais questões levantadas e verificar se o DDN100 é um serviço eficiente, haja vista a importância para a sociedade em ter uma ferramenta de denúncia rápida e eficaz no combate a violência sexual praticada contra crianças e adolescentes. 


\section{Abordagem teórico-metodológica}

A metodologia da pesquisa será um processo e não um conjunto formal de regras, que busca o conhecimento implicado no enfrentamento de uma realidade complexa e que não se desvela à primeira vista, exigindo-se, a combinação de referências teóricas e de técnicas que dêem conta da questão colocada como objeto de investigação.

A questão do circuito que se segue a denúncia e a notificação de abuso e violência sexual implica um percurso complexo que envolve diversos atores, tanto no sistema policial como no judiciário, no Ministério Público, no sistema de garantias de direitos de criança e adolescentes, nas políticas sociais, na família e na sociedade, além das pessoas envolvidas com a violência sexual denunciada. Por isso constitui etapa fundamental da pesquisa verificar cada caminho em que a denúncia passa, formalizada pelo Serviço Disque Denúncia Nacional de Abuso e Exploração Sexual de Crianças e Adolescentes. Para isso foi necessário acesso à documentação sobre o funcionamento do Serviço, entendendo sua dinâmica institucional, em como são formalizadas e notificadas as denúncias. Essa etapa foi composta de algumas entrevistas na Secretaria Especial de Direitos Humanos com pessoas responsáveis diretamente com a gestão do Serviço Disque Denúncia. foram também realizadas entrevistas no Cecria, ONG responsável pela co-gestão do Serviço.

A metodologia utilizada neste Estudo constituiu-se na coleta de dados (primários e secundários), na análise dos dados quantitativos, qualitativos e sistematização, em três momentos inter-relacionados.

A primeira parte foi de entrevistas com pessoas-chave que atuam com a temática nas instituições que fazem parte do universo da pesquisa, entre os quais, representante da Secretaria Especial dos Direitos Humanos (Cristina Albuquerque - Coordenadora do DDN - 100, Josemarrie Siqueira (Call Center) - Supervisora do Nível 1, Marli Batistella - Supervisora do Nível 2), representante do Centro de Referência, Estudos e Ações sobre Crianças e Adolescentes (Karina Figueiredo), representante da Petrobras (Wilson Santarosa) e representante do Ministério Público (Leslie Marques de Carvalho).(dados primários). Os profissionais mencionados, aos quais se direcionaram as entrevistas, receberam as informações necessárias sobre a pesquisa em ocasião anterior à realização da atividade. Neste momento, também registraram por meio da 
assinatura em um termo ${ }^{1}$ de consentimento livre e esclarecido. Estes dados foram sistematizados através de entrevistas semi-estruturadas, em busca de compreender as questões levantadas por esse Estudo. É importante destacar que as entrevistas são ferramentas importantes com instrumentos que permitem ao pesquisador observar fenômenos que não são descritos na forma escrita. Assim, ao se entrevistar pessoaschave como as que foram realizadas, a pesquisa ganha mais legitimidade. Na fala são possíveis verificar a linguagem corporal, a tonalidade da voz, os silêncios, e etc. (CFESS, ABEPSS, CEAD, UnB, 2001). Para isso foi elaborado um roteiro ${ }^{2}$ de entrevistas dividido em blocos estruturados. No primeiro bloco foram colocadas questões referentes à violência sexual contra crianças e adolescentes. No segundo bloco foram colocadas questões referentes à relação da instituição com o Serviço Disque Denúncia.

A segunda parte constituiu-se da realização de pesquisa bibliográfica, utilizando documentos de natureza oficial, referenciais teóricos, e legislações nacionais e internacionais que subsidiaram as análises deste Estudo, por meio de consulta a banco de dados do governo e de instituições da sociedade civil que são referências na temática. (dados secundários). Após a coleta, os dados foram observados de acordo com a técnica de análise de conteúdo, sendo esta amplamente utilizada pelas pesquisas sociais. Minayo (1994) destaca a utilidade desta técnica tanto na verificação da hipótese levantada quanto na descoberta do que está por trás dos conteúdos manifestados, ou seja, das aparências. Sendo assim, foram elaboradas categorias gerais de análise em momento anterior à coleta de dados, além de categorias mais específicas e concretas após a coleta do material.

Por último, o acompanhamento do processo político (em 2006) por meio da participação em reuniões estratégicas, fóruns, congressos, seminários, oficinas, encontros, comitês sobre a temática.

\footnotetext{
${ }^{1}$ Segue no anexo o Termo de Consentimento Livre e Esclarecido.

${ }^{2}$ Segue no anexo o Roteiro de Entrevista.
} 


\section{Apresentação e análise do objeto de estudo}

\subsection{Conceitos referentes à Violência Sexual contra Crianças e Adolescentes}

A violência sexual contra crianças e adolescentes é um fenômeno mundial, que esteve sempre presente em toda a história da humanidade e em todas as classes sociais, articulada ao nível do desenvolvimento civilizatório da sociedade na qual acontece.

Historicamente, observa-se que o uso do poder, das relações de força, como determinantes de direitos e deveres no que concerne á expressão do desejo sexual tem gerado uma diferença e uma assimetria numa relação de desigualdade, onde aqueles que detêm esse poder - com fins de dominação, opressão e exploração - valem-se do privilégio do livre exercício de sua sexualidade sobre aqueles que se encontram sob seu domínio, independentemente da vontade dos mesmos, especialmente em se tratando de crianças e adolescentes.

Trata-se de uma relação de poder entre desiguais, onde de encontram atores e forças com pesos desiguais de conhecimento, recursos, estratégias e organização. Segundo Machado (1979), falando de Foucault,

Os poderes não estão instalados em nenhum ponto específico da estrutura social. Funcionam como uma rede de dispositivos ou mecanismos a que nada ou ninguém escapa, a que não existe exterior possível, limites ou fronteiras...o poder não é algo que se detém como uma coisa, como uma propriedade, que se possui ou não. Não existe de um lado os que têm o poder e, de outro, aqueles que se encontram aliados do poder. Rigorosamente falando, o poder não existe; existem sim práticas ou relações de poder (Foucault, 1979:14).

Chauí reconhece que há, na violência, o desejo de sujeição/submissão e anulação da diferença do outro, passando pela internalização da vontade e ação alheias em substituição às da parte dominada. Trata-se, portanto, de uma relação dominaçãoexploração que conduz à perda da autonomia. E conclui afirmando que a violência perfeita é aquela que resulta em alienação, identificação da vontade e da ação de alguém com a vontade e a ação contrárias que a dominam. (Chaú, 1985:35).

Esta violência é transversal no Brasil, inscrevendo-se no arcabouço cultural e institucional do país, onde as políticas públicas são ainda inconsistentes, pontuais, seletivas, casualistas e sem regras estáveis ou reconhecimento de direitos, reproduzindo a miséria, a subalternidade e os antagonismos de interesses de classes, grupos e atores sociais. 
Nas últimas décadas, o quadro vem se transformando com a introdução e sedimentação de diversos conceitos, tais como direitos humanos, cidadania, gênero, infância, adolescência, violência e abusos sexuais, repercutindo na percepção de como a sociedade encara a atividade sexual entre adultos e crianças.

As crianças passaram a ser consideradas como sujeitos do direito à integridade física, psicológica e social, cabendo à sociedade a proteção desses direitos explicitados nos artigos $3^{\circ}$ e $4^{\circ}$ do ECA.

No que se refere ao arcabouço legal, os avanços se verificam a partir da promulgação da Constituição Federal, denominada Cidadã, em 1988, em que em seu Art. 227, estabelece:

Art. 227 - É dever da família, da sociedade e do Estado assegurar à criança e ao adolescente, com absoluta prioridade, o direito à vida, à saúde, ‘a alimentação, à educação, ao lazer, à profissionalização, à cultura, ao respeito, à liberdade, e a convivência familiar e comunitária, alem de colocá-los a salvo de toda forma de negligência, exploração, violência, crueldade e opressão.

Complementando pelo seu parágrafo $4^{\circ}$, que reza que a lei punirá severamente 0 abuso, a violência e a exploração sexual da criança e do adolescente.

No Estatuto da Criança do adolescente - ECA (lei $\mathrm{n}^{0}$ 8.069\90), a questão do abuso sexual é assim tratado:

Art. $5^{\circ}$ - Nenhuma criança ou adolescente será objeto de qualquer forma de negligência, discriminação, exploração, violência, crueldade e opressão, punido na forma de lei qualquer atentando, por ação ou omissão, aos seus direitos fundamentais.

Art. $130^{\circ}$ - Verificada a hipótese de maus-tratos, opressão ou abuso sexual imposta pelos pais ou responsável, a autoridade judiciária poderá determinar, como medida cautelar, o afastamento do agressor da moradia comum.

O grande diferencial se estabelece quando o abuso e violência sexual contra criança e adolescente deixa de ser uma transgressão de ordem moral, ou seja, de caráter íntimo e privado, para ser considerada também como uma transgressão social, afetando a sociedade como um todo e exigindo respostas no sentido de prevenção do fenômeno, de punição dos agressores e de criação de condições efetivas para um tratamento, considerando as suas repercussões físicas, psicológicas e sociais.

Com relação ao abuso e violência sexual não existe uma só concepção, mas sim várias concepções, que assumem distintas dimensões dependendo dos contextos sócioculturais onde se definem e que podem incluir desde carícias lascivas ao ato sexual com 
penetração. O National Center on Child Abuse and Neglect - NCCAN defende que o abuso sexual engloba:

Quaisquer contatos ou interações entre uma criança e um adulto, quando a criança é usada para a satisfação sexual do abusador ou de outra pessoa. $O$ abuso sexual pode ser cometido entre menores, desde que o agressor seja significadamente mais velho que a vítima ou quando está numa posição de poder e controle sobre a outra criança. (Clark/Clark, 1989:163).

No tocante a essa reconhecida impressão conceitual, Faleiros(1998) coloca que por tratar-se de campo teórico-prático novo e em construção, a compreensão deste fenômeno e sua concepção exigirão ainda muita investigação e sistematização.

O conceito de abuso sexual é assim compreendido pela ANDI e complementado pelo UNICEF:

Ato ou jogo sexual em que o adulto submete a criança ou o adolescente (relação de poder desigual) para se estimular ou satisfazer sexualmente, impondo-se pela força física, pela ameaça ou pela sedução, com palavras ou com a oferta de presentes. (ANDI, 2002:44) Não tem implicações comerciais, na medida que não invertem nas forças de mercado nem produz nenhum benefício secundário, do ponto de vista material (UNICEF, 2002:07).

Para Azevedo e Guerra o conceito de abuso-vitimização sexual é definido como:

Todo ato ou jogo sexual, relação heterossexual ou homossexual, entre um ou mais adultos e uma criança ou adolescente com menos de 18 anos, tentando por finalidade estimular sexualmente a criança ou utilizá-la para obter uma estimulação sexual sobre sua pessoa ou de outra pessoa (Azevedo e Guerra, 1989, 42).

A vitimização sexual pode também incluir telefonemas obscenos, exposição de genitálias ou seios, mostrar a uma criança materiais pornográficos, práticas de atos libidinosos, masturbação, relações ou tentativas sexuais orais, anais, vaginais ou exploração de crianças e adolescentes através da prostituição e/ou produção de materiais pornográficos. No caso do abuso sexual se incluem as práticas de abuso intrafamiliar, que, se cometida por parente, caracteriza-se como abuso incestuoso (conjunção carnal entre parentes consangüíneos), o abuso sexual consiste na maioria dos casos, numa demonstração de violência doméstica contra crianças e adolescentes, consistindo fenômenos endêmicos do Brasil. 


\subsection{Marco Legal Internacional e Nacional Referente à Exploração dos Direitos de Crianças e Adolescentes.}

A violação dos direitos sexuais contra crianças e adolescentes no Brasil teve sua expressão política na década de 1990, quando o fenômeno, fruto das desigualdades sociais, de gênero, de raça e etnia foi incluído na agenda da sociedade civil como questão relacionada à luta nacional e internacional pelos direitos humanos de crianças e adolescentes, estabelecidos na Constituição da República do Brasil, no estatuto da criança e do adolescente (Lei Federal $n^{\circ} 8.069$, de 13 de julho de 1990) e na Convenção Internacional dos Direitos da Criança. Este período foi marcado por um forte processo de articulação, mobilização e por experiências consolidadas que fortaleceram a sociedade para assumir a denúncia como forma de enfrentamento da violência sexual, o que significou um marco histórico na luta dos direitos da criança e do adolescente.(Cecria, 1997)

O reconhecimento dos direitos de cidadania à criança e ao adolescente é a conquista mais recente da evolução história dos direitos humanos. No Brasil, é representada pela promulgação do ECA, em 13 de julho de 1990. Ele traduz na prática o compromisso do país com a Convenção sobre o Direito da Criança, aprovada pela assembléia-geral da ONU em 20 de novembro de 1989 e pelo Congresso Nacional Brasileiro em 14 de setembro de 1990, através do decreto legislativo n 28.

Neste capítulo serão apontadas as principais legislações, nacionais e internacionais, pertinentes ao combate à exploração e o abuso sexual contra crianças e adolescentes.

\subsubsection{Garantia de direitos}

A palavra “direito” tem diversos significados. Na maior parte das vezes utilizase a expressão para falar de um sistema ${ }^{3}$, formado por regras - as normas jurídicas que regulam a convivência das pessoas em sociedade. Assim o art $5^{\circ}$ da CF, que protege a "vida" de todos os brasileiros e estrangeiros residentes no país, associado ao art. 121 do Código Penal, estabelece pena de reclusão para quem “matar alguém”. São normas

\footnotetext{
${ }^{3}$ Segundo Porto (1999) é o conjunto de elementos articulados segundo um princípio de funcionamento comum.
} 
que determinam a todas as pessoas o respeito à vida dos seus semelhantes para que possam continuar convivendo em sociedade.

Art $5^{\circ} \mathrm{CF}$ - todos são iguais perante a lei, sem distinção de qualquer natureza, garantindo-se, aos brasileiros e aos estrangeiros residentes no País a inviolabilidade do direito à vida (...)

Art $121 \mathrm{CPB}$ - matar alguém:

Pena - reclusão, de 6 (seis) a 20 (vinte) anos.

Mas, se a expressão direito pode indicar o conjunto de normas, do ponto de vista de quem impõe essas normas - o Estado - ela também pode significar a faculdade ou poder de agir de cada uma das pessoas, diante das mais diferentes situações(Hazeau, 1996). Quando nos referimos ao conjunto de regras impostas pelo Poder Público, a quem todos devemos obedecer, estamos falando do direito objetivo ${ }^{4}$. Quando olhamos do ponto de vista do destinatário das normas podemos falar de direito subjetivo ${ }^{5}$.

\subsubsection{Direitos Humanos}

Existem certos direitos, muito relevantes, protegidos hoje em dia pela lei de todos os Estados. Podemos destacar os direitos à vida, à liberdade, à segurança, à propriedade, ao trabalho, à opinião, à livre associação, etc. As Constituições de quase todos os países dedicam capítulos especiais a esses direitos.

Não precisaríamos ir muito longe na história para nos lembrarmos que nos governos tirânicos, o rei tinha poderes ilimitados e os cidadãos não possuíam quase nenhum direito. A qualquer momento poderiam perder seus bens, ser presos injustamente, ter suas vidas ameaçadas. A lei do país não garantia os direitos fundamentais das pessoas.

Nesses países se iniciaram movimentos visando a garantir que a vida, a liberdade, a propriedade, enfim, todos os direitos fundamentais da pessoa humana fossem respeitados. Em defesa dos cidadãos, alegava-se, que todo homem ou mulher nascia com tais direitos, que existiam mesmo antes de existir o Estado, o Governo, o Rei ou qualquer outro governante. Eram direitos naturais presentes no homem em

\footnotetext{
${ }^{4}$ Segundo (Passos, 1999) o direito objetivo é um conjunto de normas (Constituição, leis, decretos, regulamentos etc.) impostas pelo estado, e que obrigam a todos os cidadãos. O direito objetivo é também chamado de direito positivo.

${ }^{5}$ Segundo (Passos, 1999) o direito subjetivo é a faculdade ou poder de agir que as normas (direito objetivo) conferem ao cidadão; é o direito visto do ângulo do sujeito.
} 
decorrência de sua própria natureza. Portanto, o conjunto de direitos subjetivos básicos inerentes a todos os seres humanos, independentemente de sua raça, cor, sexo, nacionalidade ou classe social e que os protegem do Estado e dos demais cidadãos constitui os direitos humanos. (Mesquita, 2002)

O inglês John Locke (1978) em sua obra Segundo Tratado sobre o Governo Civil, afirmou que os poderes do soberano eram limitados, e que os cidadãos tinham o direito subjetivo de reagir contra os abusos e a tirania. Esse direito subjetivo não vinha unicamente da natureza, mas deveria estar contido no próprio direito positivo.

Das idéias de Locke (1978) vem o conceito de Estado-de-Direito. Entendido como um Estado no qual os órgãos supremos de poder - aqueles que impõem as normas, no caso o Executivo e o Legislativo - submetem-se às mesmas normas que são impostas aos cidadãos.

\subsubsection{Os Direitos da Criança}

Embora a luta histórica pelos direitos humanos seja sempre no sentido de incluir mais uma categoria social como beneficiária da proteção do estado, só a partir do século XVI é que as crianças passaram a ser vistas como uma categoria social diferenciada. A criança nunca foi vista como um cidadão completo, tinha poucos deveres e, conseqüentemente, poucos direitos. Até o século passado, o mesmo sistema penal era aplicado à adultos e crianças, independentemente de sua idade. (Costa, 1992)

A legislação internacional para proteção aos direitos humanos das crianças começou na ratificação, em 26 de setembro de 1923, da Declaração sobre os Direitos da Criança, em Genebra. Após isso com a Declaração Universal dos Direitos Humanos, promulgada pela ONU em 1948. Em 1959, as Nações Unidas editaram a Declaração Universal dos Direitos da Criança. Em 1989, os países que formavam a ONU construíram a Convenção sobre o Direito da Criança, aprovada pela Assembléia-Geral das Nações Unidas em 20 de novembro de 1989 e pelo Congresso Nacional Brasileiro em 14 de setembro de 1990, através do Decreto Legislativo 28. A ratificação ocorreu com a publicação do decreto 99.710 de 21 de novembro de 1990, através do qual o Presidente da República promulgou a Convenção, transformando esta em lei interna.

A legislação brasileira, com a Constituição Federal de 1988, coloca plenas garantias do Estado de Direto, definindo proteção à família e colocando como sujeitos de direitos (artigos 226 e 227) crianças e adolescentes. O Estatuto da Criança e do 
Adolescente (lei 8.069 de 13 de julho de 1990) enumera os direitos da criança e do adolescente colocando a garantia de seus direitos e de sua proteção integrada e integral.

\subsubsection{A Convenção Internacional sobre o Direito da Criança 1989}

A Convenção das Nações Unidas é apresentada como instrumento de domesticação do poder parental e estatal, principalmente nas suas relações autoritárias, com a infância e a adolescência, como instrumento de mobilização da sociedade e de construção de uma nova cultura institucional que veja a criança e o adolescente como cidadãos e como mobilizadores no processo de institucionalização de um sistema de garantia de direitos eficiente e eficaz.

A Convenção das Nações Unidas sobre os Direitos da Criança assegura prerrogativas que a Sociedade e o Estado devem conferir à criança e ao adolescente, para operacionalizar a garantia dos seus direitos. A Convenção pode e deve ser poderosa aliada numa luta política pela garantia de parcela de poder para a infância e a adolescência, em um novo modelo de convivência que não faça, da criança e do adolescente, coisas, objetos, dominados. A Convenção teve um grande mérito de tornar indisponíveis e exigíveis os direitos de todas as crianças e de todos os adolescentes. O mais importante foi colocar na necessidade da efetivação da norma, da implantação e implementação de um sistema de garantia de direitos e mecanismos de promoção e defesa de direitos e de controle social desses espaços e mecanismos.

A Convenção sobre os Direitos da Criança ao colocar o combate à exploração sexual como destaque, conforme descrito no artigo 34, caracteriza um sistema de garantia de direitos que depende do seu grau de legitimidade, isto é, do compromisso que seus destinatários e seus aplicadores assumem com ela.

Art 34- Os Estados Partes se comprometem a proteger a criança contra todas as formas de exploração e abuso sexual. Nesse sentido os Estados Partes tomarão, em especial, todas as medidas de caráter nacional e multilateral que sejam necessárias para impedir:

a)o incentivo ou a coação para que uma criança se dedique a qualquer atividade sexual ilegal;

b)a exploração da criança na prostituição ou outras práticas sexuais ilegais;

c) a exploração da criança em espetáculos ou matérias pornográficos. 
Seria importante se conseguíssemos tornar realmente conhecida e efetiva a convenção sobre os Direitos da Criança de 1989. Seria importante tratar, por conseqüência, essencial e substantivamente as crianças e os adolescentes como pessoas em desenvolvimento e ao mesmo tempo sujeitos de direito. Ao contrário disso as crianças e adolescentes são tratados a partir de adjetivações como: vulnerabilizadas, vitimadas, crianças e adolescentes em crise, em risco ou em perigo, em desvantagem social, em conflito com a lei ou ainda, estigmatizados como meninos de rua, pivetes, delinqüentes, ou seja, sempre levando em conta a idéia da excepcionalidade, fragilidade e negatividade.

Dessa maneira o discurso do Direito protagonizado pela Convenção que trata crianças e adolescentes como cidadãos, com direitos e deveres, participando da vida social proativamente e sendo protegidos na medida de suas necessidades, entretanto o discurso enfrenta o tradicional discurso hegemônico. Em função disso a Convenção pode-se tornar inaplicável e sem operacionalização.

A Convenção pode e deve ser aliada numa luta política pela garantia de parcela de poder para a infância e a adolescência. Uma aliada no processo de transformação da nossa cultura institucional autoritária, de relação aos reconhecidos por ela como "mais fracos”, os dominados. A Convenção tornou indisponíveis e exigíveis os direitos de todas as crianças e adolescentes. O mais importante dessa Convenção não foi a criação de "novos direitos" da criança e do adolescente, propriamente. Mas sim, a efetivação da norma, da implantação e implementação de um sistema de garantia de direitos, isto é, espaços públicos institucionais e mecanismos de promoção e defesa dos direitos e de controle social desses espaços e mecanismos.

\subsubsection{Constituição Federal de 1988}

A Constituição Federal de 1988 constitui um grande avanço na defesa de diversos direitos entre eles a proteção integral e integrada da criança e do adolescente colocando-os como sujeitos de direito. Essa nova concepção possibilita uma mudança nos aspectos culturais relacionados com a inferioridade/subordinação, na qual a violência se manifesta, cresce, se legitima e se consolida. A Carta Magna evidencia em seu artigo 227 capítulo VII:

Art 227. É dever da família, da sociedade e do Estado assegurar à criança e ao adolescente, com absoluta prioridade, o direito à vida, à saúde, à alimentação, 
à educação, ao lazer, à profissionalização, à cultura, à dignidade, ao respeito, à liberdade à convivência familiar e comunitária, além de colocá-los a salvo de toda forma de negligência, descriminação, exploração, violência, crueldade e opressão.

$\S 4^{\circ} \mathrm{A}$ lei punirá severamente o abuso, a violência e a exploração sexual da criança e do adolescente.

A CF foi um enorme avanço em relação as anteriores leis. Nela é possível verificar no artigo descrito a sua preocupação com os direitos fundamentais da criança e do adolescente, coibindo qualquer forma de abuso, violência e a exploração sexual da criança e do adolescente. Por isso, nossa Constituição de 1988 deve ser lembrada em todas as ações desenvolvidas no tocante a criação de novas políticas, programas, serviços e ações. A CF deixa bem claro que é dever de todos a proteção a criança e ao adolescente, incluindo a família, a sociedade e, claro, o Estado.

\subsubsection{Internalização dos tratados e convenções assinados pelo Estado brasileiro}

Para que tratados, convenções, acordos internacionais como a Convenção dos Direitos da Criança de 1989 terem aplicabilidade na legislação nacional é necessário um ordenamento pré-estabelecido pela Constituição de 1988. (Casali Júnior, 2000)

O Chefe de Estado afirma, no âmbito internacional, o tratado ou convenção. A seguir o ato é submetido à aprovação definitiva do Congresso Nacional. O que acontece por meio de decreto legislativo ${ }^{6}$ (inciso I do artigo 49 da CF de 1988).Uma vez aprovada pelo Congresso Nacional, o ato internacional é promulgado. Essa promulgação se dá por decreto presidencial. É quando o tratado ou convenção é, de fato, internalizado, passando a ter eficácia na Legislação Nacional.

É importante esclarecer, ainda, que o tratado internacional, seja qual for a sua matéria, inclusive direitos humanos ingressa no Direito brasileiro com hierarquia de lei ordinária federal. A emenda $n^{\circ} 45$ de 31 de dezembro de 2004 acrescentou o seguinte parágrafo $3^{\circ}$ ao artigo $5^{\circ}$ da CF de 1988:

"Os tratados e convenções internacionais sobre direitos humanos que forem aprovados, em cada casa do Congresso Nacional, em dois turnos, por três quintos dos votos dos respectivos membros, serão equivalentes às emendas constitucionais."

\footnotetext{
${ }^{6}$ O Decreto legislativo é uma espécie normativa proveniente do Congresso Nacional, com a mesma hierarquia de uma lei ordinária, mas que não necessita de sanção por parte do Presidente da República.
} 


\subsubsection{Estatuto da Criança e do Adolescente}

O Estatuto é apresentado, em essência, como uma norma geral de proteção integral da criança e do adolescente, através da garantia de seus direitos quando ameaçados ou violados. Explicitam-se os princípios e as diretrizes do Estatuto e suas linhas de ação sistêmica, articuladas e integradas: a política de atendimento de direitos, o acesso à justiça e o controle social externo da sociedade mobilizada. (Costa, 1991)

Em obediência à constituição federal (art. 24, XV e 30, II) e com decorrência a doutrina jurídica de Proteção Integral, consagrada na Convenção das Nações Unidas sobre o Direito da Criança, fala-se hoje em legislação sobre proteção da criança e do adolescente - matéria concorrente da União, dos Estados, do Distrito Federal e dos Municípios. Com a revogação do Código de Menores e com a promulgação do Estatuto da Criança e do Adolescente (lei federal 8.069), em 13 de julho de 1999, com vigência no mesmo ano, não há mais que se falar em um “direito de Menores”.

O Estatuto não é nenhuma consolidação das normas de um ramo especial do Direito. Traz substancialmente normas de direito civil, direito trabalhista, direito processual, direito administrativo e etc. A legislação propõe, por exemplo, proteger o adolescente nas suas relações trabalhistas, proteger a criança e o adolescente em suas relações civis familiares e futuras, proteger o adolescente em suas relações com o Estado quando da solução do seu conflito (com relação processual, isto é, como garantia da liberdade, da dignidade e da integralidade), além de proteger a criança e o adolescente quando do seu acesso aos serviços e programas da esfera pública.

Nesse sentido, o artigo 227 da Constituição Federal, que consagra normas programáticas, reconhecendo e garantido, em sede constitucional, os direitos fundamentais comuns e especiais da criança e do adolescente. Uma legislação tão importante deveria ser superior à legislação infra-constitucional ordinária, sendo aprovada como lei complementar, mas por razões políticas e conjunturais não foi permitida na época. Em resumo, o Estatuto da Criança e do Adolescente é um sistema jurídico-político-institucional de garantias dos direitos da criança e do adolescente, para protegê-los de modo integral. 


\subsubsection{Princípios do Estatuto da Criança e do Adolescente}

O Estatuto da Criança e do Adolescente propõe regular um sistema de garantias a partir de alguns princípios, entre a máxima priorização, a descentralização políticoadministrativa e por fim a participação popular. Cabe agora falar um pouco sobre cada um desses princípios.

A máxima priorização ou prioridade absoluta, da efetivação dos direitos da criança e do adolescente, princípio do qual segue a linha da Convenção Internacional sobre o Direito da Criança, onde coloca o direito da criança como preferência sobre os demais. O interesse da prevalência se faz direito, ao ser declarado ou constituído em uma situação de fato. A primazia, por exemplo, de receber proteção e socorro, precedência no atendimento público, preferência na formulação e execução das políticas e destinação privilegiada de recursos públicos.

Esse princípio se torna a justificativa de muitas ações judiciais para garantir determinados direitos da criança e do adolescente, quando violados. Nesse sentido à um reconhecimento da prevalência do melhor interesse da criança e da prioridade do seu atendimento.

O princípio da descentralização político-administrativa, que atribui: a) à União, fixar normas gerais e coordenar administrativa e politicamente a descentralização; b) aos Estados e Municípios, coordenar e executar programas.

O próximo princípio, da participação social, enfatizada pelo ECA, “ por meio de organizações sociais representativas, na formulação de políticas públicas nos controles, nos 3 níveis (federal, estadual e municipal)”. Um dos componentes do novo paradigma $^{5}$ político-institucional contido na CF de 1988 consiste na idéia do fortalecimento dos movimentos populares, do fortalecimento da participação direta da população através de suas organizações representativas (art.204, II).

Primeiramente, é preciso que se reconheça a legitimidade de ambos (representação e participação); é necessário que partidos políticos, sindicatos e expressões do movimento social se relacionem de modo “correto” sem manipulações e aparelhamentos. É indiscutível a validade da luta social, da denúncia, do embate no seio das instâncias da sociedade civil (fórum, frentes, conselhos, etc). É necessário que a luta

\footnotetext{
${ }^{5}$ Paradigma “.... efetua a seleção e a determinação da conceptualização e das operações lógicas. Designa as categorias do seu emprego. Assim, os indivíduos conhecem, pensam e agem segundo paradigmas inscritos culturalmente neles”. (Edgard Morin, p.25)
} 
seja no espaço da chamada luta institucional, como pretende o ECA, quando fala em “participação popular paritária por meio das organizações”. Esses espaços institucionais públicos estão previstos como locus da mediação.

\subsubsection{Diretrizes do ECA}

As principais diretrizes propostas pelo Estatuto são a municipalização e a descentralização político administrativa. O ECA contempla, assim, um esquema de cooperação e distribuição de competências entre União, estados e municípios, estendendo-se a organizações não governamentais e à sociedade civil organizada. Prevê, por exemplo, a criação de Conselhos de Diretos da Criança e do Adolescente em nível nacional, estadual e municipal, sob o fundamento de que o âmbito local e comunitário é mais propício à promoção de direitos da infância e juventude. Esta articulação pressupõe, conseqüentemente, a organização de uma rede de serviços de responsabilidade compartilhada por todos os entes políticos da federação.

Outra diretriz da política de atendimento dos direitos da criança e do adolescente é a integração operacional de órgãos tais como o Judiciário, o Ministério Público, a Defensoria Pública e Delegacias Especializadas. Esta integração operacional tem por escopo uma agilidade no que tange questões envolvendo direitos da criança e do adolescente, assegurando-se, com isso, o princípio constitucional da prioridade absoluta.

A participação e o controle social também são diretrizes significativas do Sistema de Garantias de Direitos da Criança e do Adolescente. Por esta razão, a responsabilidade pela promoção dos direitos da criança e do adolescente entre a família, a sociedade e o Estado é equânime; para se possibilitar a integração destes três protagonistas o ECA criou órgãos como os Conselhos de Direitos e os Conselhos Tutelares.

Por fim, de forma a promover a efetivação da política de atendimento, o ECA ordenou a criação de órgãos específicos pelo governo e pela sociedade civil organizada capazes de atender às diretrizes expostas, tais como os já citados Conselhos de Direito da Criança e do Adolescente, os Conselhos Tutelares, as Delegacias Especializadas, as Defensorias Públicas, as Varas e Promotorias Especializadas da Infância a da Juventude e os Centros de Defesa da Criança e do Adolescente. O conjunto destes órgãos nada mais é do que a concretização do próprio Sistema de Garantias de Direitos da Criança e do Adolescente. 


\subsubsection{Direitos Fundamentais do ECA}

De modo análogo ao que a Constituição Federal explica no art $5^{\circ}$ para todos os cidadãos, o Estatuto declara no título II os direitos fundamentais da criança e do adolescente. Em doze artigos, amplia a formulação dos direitos enunciados no art. 227 da Constituição.

O Estatuto é dividido em duas partes: Geral e Especial. A primeira expõe os direitos fundamentais e do adolescente. A parte especial mostra os instrumentos para pôr em prática tais direitos. A doutrina da proteção integral, base do Estatuto, reconhece as crianças e adolescentes como cidadãos, possuidores de todos os direitos dos adultos, e de outros direitos especiais, por serem pessoas em desenvolvimento. Diz o art. $3^{\circ}$ do Estatuto:

"Art. $3^{\circ}$. A criança e o adolescente gozam de todos os direitos fundamentais inerentes à pessoa humana, sem prejuízo da proteção integral de que trata esta lei, assegurando-se-lhes, por lei ou por outros meios, todas as oportunidades e facilidades, a fim de lhes facultar o desenvolvimento físico, mental, moral, espiritual e social, em condições de liberdade e dignidade”.

O texto é bem claro: as crianças e adolescentes "gozam de todos os direitos fundamentais”, além da proteção integral de que trata o Estatuto. Isto é, todos os direitos que se encontram no art. $5^{\circ}$ da CF e em outras leis estendidos a criança e ao adolescente e se aplicam imediatamente.

\subsubsection{Avanços do Estatuto em face à legislação anterior revogada}

O confronto de duas leis que regulam os direitos da criança e do adolescente - 0 Código de Menores e o ECA - é na verdade, o confronto de duas doutrinas, e sobretudo de duas visões jurídicas, sobre a criança: a doutrina de Situação Irregular e a Doutrina da Proteção Integral. O ECA traduz esta última em lei, que está em vigor desde 1990, dividindo até hoje opiniões e práticas quanto ao modo de cuidar as crianças e adolescentes. Para falar dos avanços do ECA é necessário uma comparação com a lei que, anteriormente, vinha cuidando das crianças e adolescentes do país: o Código de Menores, de 1979. 
Não obstante os avanços científicos que já se faziam presentes, no final da década de setenta, entendeu, o regime militar, de produzir uma lei que ignorava todas aquelas conquistas, optando por centralizar, na figura do juiz de menores, os aspectos relativos à criança e ao adolescente. O Código de Menores tinha um alvo preferencial, os menores que se encontravam em situação irregular, que foi o termo encontrado para as situações que fugiam ao padrão normal da sociedade em que se pensava viver. Estavam em situação irregular os abandonados, vítimas de maus-tratos, miseráveis e infratores. Enquadrando-se em qualquer das hipóteses enumeradas no artigo $2^{\circ}$ do Código - 10 situações descritas, no total - o “menor" passava à autoridade do juiz de menores, que aplicava “em sua defesa”, os preceitos do Código de Menores.

Vamos agora evidenciar alguns artigos do Código de Menores que diferem da proposta do ECA. Os Artigos $4^{\circ}$ e $5^{\circ}$ estabeleciam o modo de interpretação da lei. A do artigo $5^{\circ}$ era, no mínimo, estranho: “Art. 5. Na aplicação desta lei, a proteção aos interesses do menor sobrelevara qualquer outro bem ou interesse juridicamente tutelado”. O Juiz passava a ter, sob esse discurso, possibilidade de decidir como bem entendesse, relevando quaisquer outras normas, ainda que superiores ao Código.

$\mathrm{O}$ art. $8^{\circ}$ dava ao juiz de menores poderes para editar normas de caráter geral, suplementando a legislação. “Art. $8^{\circ}$. A autoridade judiciária, além das medidas especiais previstas nessa Lei, poderá, através de portaria ou provimento, determinar outras de ordem geral, que, ao seu prudente arbítrio, se demonstrem necessárias à assistência, proteção e vigilância ao menor, respondendo por abuso ou desvio de poder”. Desta maneira, ele possuía poderes para interpretar, aplicar e mesmo criar as normas que, afinal, interpretaria e aplicaria. Algo inaceitável em um Estado de Direito, caracterizado pela divisão e harmonia entre os Poderes.

Com relação ao Código merece destaque a apuração da autoria de infração penal, que se dava com base nos artigos 99 e seguintes do CM. O procedimento não era contraditório $^{8}$, ou seja, não havia direito de defesa. O juiz comandava a apuração, apenas fiscalizada pelo Ministério Público, na condição de curador. O chamado “menor” se praticasse algum delito em companhia de adulto, poderia, a critério do juiz, ou por solicitação de autoridade policial ficar à disposição, por um prazo de cinco dias, antes do procedimento de apuração de infração penal. Portanto, a polícia tinha cinco

\footnotetext{
${ }^{8}$ Contraditório significa o direito que o acusado possui de contradizer, de contestar aquilo que dizem a seu respeito. O contraditório é garantido na Constituição Brasileira em seu artigo $5^{\circ}$, inciso LV, "art. $5^{\circ}$ $L V$ - aos litigantes, em processo judicial ou administrativo, e aos acusados em geral são assegurados o contraditório e a ampla defesa, com os meios e recurso a ela inerentes".
} 
dias para utilizar o suposto infrator em diligências, interrogatórios, acareações, prevalecendo o interesse da investigação sobre a integridade moral do "menor".

Os reflexos da aplicação do Código de Menores na vida das crianças e adolescentes foram severos. Existiam constantes violações de direitos por parte dos órgãos do próprio Estado, como exemplo a polícia, além das privações de liberdade sem contraditório, a visão estreita, preconceituosa, discriminadora, que a sociedade possuía dos “menores”, sobretudo dos erros cometidos na elaboração do Código.

O Estatuto da Criança e do Adolescente diferentemente do Código de Menores adota a doutrina de proteção integral, poderíamos resumir como principais avanços do Estatuto: em primeiro lugar a destinação da Lei, onde coloca todas as crianças e adolescentes protegidos por disposições estatutárias. Com isso visa-se a integração de setores excluídos, como os muito carentes ou em conflito com a lei, sem tratamento diferenciado que geraria, necessariamente, a exclusão. Em segundo lugar, existe uma preocupação extrema da Lei com os direitos fundamentais, como as garantias de exames pré e perinatal, teste do pezinho, na área de saúde ou a garantia de educação pública e gratuita, proteção no trabalho, qualquer tipo de violência, abuso ou exploração da criança e do adolescente etc. Outro avanço do Estatuto foi de modificar a parte de prevenção, a qual foi restringida à itens básicos, com redução de poderes das autoridades para não prejudicarem as crianças e adolescentes com determinações extremas e autoritárias. Houve uma simplificação de procedimentos, e o poder do juiz de emitir normas, tomar decisões autoritárias, assim como era no Código de Menores com o dito juiz de menores, foi restringida pelo ECA. Mas o maior avanço foi a montagem de um verdadeiro sistema de garantia de direitos, que inclui os eixos de Promoção da Defesa e do Controle Social. Nesse sistema, os chamados atores políticos tiveram competências bem distribuídas de acordo com suas funções no aparelho do Estado. 
Podemos analisar as principais diferenças de acordo com a tabela a abaixo:

Tabela 1. Sistematização das Principais Diferenças entra ECA e Código de Menores

\begin{tabular}{|c|c|c|}
\hline $\begin{array}{l}\text { Principais } \\
\text { mudanças }\end{array}$ & Código de Menores & ECA \\
\hline Base da doutrina & $\begin{array}{l}\text { Direito tutelar do menor, objeto } \\
\text { de medidas judiciais quando se } \\
\text { encontra em situação irregular. }\end{array}$ & $\begin{array}{l}\text { A lei assegura os direitos de todas as } \\
\text { crianças e adolescentes, sem } \\
\text { discriminação de qualquer tipo, que } \\
\text { são considerados “pessoas em } \\
\text { condição peculiar de } \\
\text { desenvolvimento”. }\end{array}$ \\
\hline $\begin{array}{l}\text { Concepção político- } \\
\text { social }\end{array}$ & $\begin{array}{l}\text { Instrumento de controle social } \\
\text { dirigido às vítimas de omissões e } \\
\text { transgressões da família, da } \\
\text { sociedade e do Estado. }\end{array}$ & $\begin{array}{l}\text { Instrumento de desenvolvimento } \\
\text { social, garantindo proteção especial } \\
\text { àquele segmento considerado pessoal e } \\
\text { socialmente mais sensível. }\end{array}$ \\
\hline Infração & $\begin{array}{l}\text { Todos os casos de infração penal } \\
\text { passam pelo juiz. }\end{array}$ & $\begin{array}{l}\text { Os casos de infração que não } \\
\text { impliquem grave ameaça podem ser } \\
\text { beneficiados pela remissão (perdão) } \\
\text { como forma de exclusão ou suspensão } \\
\text { do processo. }\end{array}$ \\
\hline Apreensão & Preconiza a prisão cautelar. & $\begin{array}{l}\text { Restringe a apreensão apenas a dois } \\
\text { casos: • flagrante delito de infração } \\
\text { penal • ordem expressa e } \\
\text { fundamentada do juiz }\end{array}$ \\
\hline Internamento & $\begin{array}{l}\text { Medida aplicável às crianças e } \\
\text { adolescentes sem tempo e } \\
\text { condições determinados, quando } \\
\text { "manifesta incapacidade dos pais } \\
\text { para mantê-los”. }\end{array}$ & $\begin{array}{l}\text { Medida só aplicável a adolescentes } \\
\text { autores de ato infracional grave, } \\
\text { obedecidos os princípios de brevidade, } \\
\text { excepcionalidade e respeito à sua } \\
\text { condição peculiar de pessoa em } \\
\text { desenvolvimento. }\end{array}$ \\
\hline Direito de defesa & $\begin{array}{l}\text { O menor acusado de infração } \\
\text { penal é “defendido” pelo curador } \\
\text { de menores (promotor público). }\end{array}$ & $\begin{array}{l}\text { Garante ao adolescente defesa técnica } \\
\text { por profissional habilitado (advogado). }\end{array}$ \\
\hline $\begin{array}{l}\text { Crimes e infrações } \\
\text { cometidas contra } \\
\text { crianças e } \\
\text { adolescentes }\end{array}$ & É omisso a esse respeito. & $\begin{array}{l}\text { Pune o abuso do pátrio poder, das } \\
\text { autoridades e dos responsáveis pelas } \\
\text { crianças e adolescentes. }\end{array}$ \\
\hline Políticas públicas & $\begin{array}{l}\text { As medidas previstas restringem- } \\
\text { se ao âmbito da: } \\
\text { - Política Nacional de Bem-Estar } \\
\text { Social (FUNABEM) } \\
\text { - Segurança pública } \\
\text { - Justiça Menores } \\
\end{array}$ & $\begin{array}{l}\text { - Políticas sociais básicas } \\
\text { - Políticas assistencialistas } \\
\text { - Serviços de proteção e defesa das } \\
\text { crianças e adolescentes vitimizados } \\
\text { - Proteção jurídico-social }\end{array}$ \\
\hline $\begin{array}{l}\text { Mecanismos de } \\
\text { participação }\end{array}$ & $\begin{array}{l}\text { Não abre espaço à participação de } \\
\text { outros atores que limitem os } \\
\text { poderes da autoridade policial, } \\
\text { judiciária e administrativa. }\end{array}$ & $\begin{array}{l}\text { Institui instâncias colegiadas de } \\
\text { participação nos níveis federal, } \\
\text { estadual e municipal (conselhos } \\
\text { paritários Estado-sociedade). }\end{array}$ \\
\hline
\end{tabular}

Fonte: Fundação ABRINQ 


\subsection{Serviço Disque Denúncia Nacional de Abuso e Exploração Sexual de Crianças e Adolescentes. - DDN - 100}

A SEDH/PR, por meio da Subsecretaria de Proteção aos Direitos da Criança e do Adolescente (SPDCA), coordena o Programa Nacional de Combate ao Abuso e à Exploração Sexual de Crianças e Adolescentes, que prioriza, dentre outras ações, o enfrentamento da exploração sexual comercial, incluindo o tráfico de crianças e adolescentes para fins de exploração sexual. "A Secretaria tem buscado a integração de um conjunto de programas e ações de governo, organismos e agências internacionais, universidade e sociedade civil, para que, por meio de ações intersetoriais articuladas, possa superar esta grave violação dos direitos das crianças e dos adolescentes”. (Cristina Albuquerque - Entrev. 15/02/07)

O Disque Denúncia Nacional de Abuso e Exploração Sexual de Crianças e Adolescentes é uma das prioridades da Secretaria Especial dos Direitos Humanos. Executado dede 1997 pela Associação Brasileira Multiprofissional de proteção à infância e à adolescência (Abrapia), com o apoio do Ministério da Justiça e da Empresa Brasileira de Turismo (Embratur), em maio de 2003 o serviço (serviço DDG Discagem Direta Gratuita de âmbito nacional) passa a ser coordenado e executado pela SEDH, em parceria com o Ministério da Saúde e o Centro de Referência, Estudos e Ações sobre Crianças e Adolescentes (Cecria). A partir de 2004, o Disque Denúncia Nacional passa a ser apoiado financeiramente pela Petróleo Brasileiro S.A - Petrobras.

O principal objetivo do Disque Denúncia Nacional é acolher denúncias de violência contra crianças e adolescentes, buscando interromper ou evitar a situação de violência revelada na denúncia (Josemarrie Siqueira - Entrev. 29/01/07). O Serviço funciona diariamente de 08:00h às 22:00h, inclusive finais de semana e feriados. As denúncias são encaminhadas aos órgãos de defesa e responsabilização, conforme competência e atribuições específicas.

O Serviço acolhe denúncias não só de violência sexual contra crianças e adolescentes. Cerca de 45\% das denúncias são referentes a situações de negligência e maus-tratos (Marli Batistella - Entrev. 16/11/06). Por meio de parceria com a Secretaria Nacional de Justiça, do Ministério da Justiça, acolhe, ainda, denúncias sobre o tráfico de pessoas adultas. No final de 2005, o DDN-100 passou a acolher notícias do paradeiro de crianças e adolescentes desaparecidos e a prestar informações acerca dos procedimentos a serem adotados nos casos de desaparecimento. 
Atualmente, o Disque Denúncia Nacional realiza, em média, 2.482 (dois mil quatrocentas e oitenta e dois) atendimentos humanos por dia, gerando 42 denúncias. De maio de 2003 a março de 2007 o DDN-100 recebeu e encaminhou 30.747 notificações.O Disque Denúncia também foi planejado para ser fonte de informações para subsidiar políticas públicas da área de enfrentamento da violência sexual contra crianças e adolescentes. O Serviço procede sistematicamente à análise do banco de dados gerado pelo Sistema Informatizado de Registro de Denúncias, onde se obtém os mais diversos perfis. (Cristina Albuquerque - Entrev. 15/02/07).

\subsubsection{Histórico do Serviço}

A implantação do Disque Denúncia, e articulação com todos os serviços de notificação e com os organismos de defesa e responsabilização, representa o cumprimento da prioridade de acordo com as legislações específicas no contexto da responsabilização de autores de violência sexual contra crianças e adolescentes. Para a Secretaria Especial dos Direitos Humanos, esse serviço representa fonte importante e inesgotável de conhecimento de fatores que contribuem para a violação de direitos da criança e do adolescente. A abordagem dos casos de violência, além de ajudar na criação de um banco de dados, permite a elaboração de indicadores qualificados para as políticas de garantia de direitos.

Com a conclusão da CPI sobre a prostituição infantil, em 14 de setembro de 1994, o Congresso Nacional lançou a Campanha Nacional pelo Fim da Violência, Exploração e Turismo Sexual contra crianças e adolescentes e tornou-se necessária a implantação de uma rede de comunicação nacional e internacional, articulada com um sistema de notificação e denúncia de crimes praticados contra crianças e adolescentes.

Por isso, em fevereiro de 1997, foi criado um Sistema Nacional de Denúncia por Telefone -0800 - sob coordenação, monitoramento e operacionalização da Abrapia (RJ). O Sistema foi fruto de um convênio do Ministério da Justiça com a Empresa Brasileira de Turismo - Embratur, que durou até março de 2003. Apesar do término do convênio, prevaleceu a certeza de que seria importante garantir a continuidade do serviço para receber denúncias por telefone (Karina Figueiredo - Entrev. 22/11/06). Essa convicção levou a Secretaria Especial de Direitos Humanos - SEDH, da Presidência da República, 
a reativar o sistema. A reativação resultou de uma parceria entre os Ministérios da Saúde e do Turismo e a sociedade civil.

Entre janeiro de 1997 e janeiro de 2003, foram recebidas 50.412 chamadas telefônicas, das quais cerca de 10\% (4.893 denúncias) eram referentes a casos de abuso e exploração sexual. (Marli Batistella - Entrev. 16/11/06).

As ocorrências intrafamiliares eram maioria, correspondendo a 81,6\% das denúncias. O Estado recordista foi o Rio de Janeiro, com 25\% das ligações (Estado onde se localizava a Ong). Roraima foi o que menos ligou, com apenas uma chamada ao longo dos seis anos.

Em 2003, o convênio da Abrapia com o Governo Federal foi encerrado e, desde então, o Disque Denúncia está sob a responsabilidade da SEDH. Esta tem como missão a execução da política de Direitos Humanos do Estado brasileiro, e neste contexto coordena e executa a Política de Garantia de Direitos de Crianças e Adolescentes. Nesta perspectiva, implantou o serviço Disque Denúncia Nacional de Abuso e Exploração Sexual de Crianças e Adolescentes, visando a oferecer à população um serviço unificado de registros de denúncias de acesso rápido e gratuito, com qualidade no atendimento, celeridade e eficácia nos encaminhamentos e monitoramento das denúncias/notificações, como ação estratégica de implementação do Plano Nacional de Enfrentamento à violência Sexual Infanto-Juvenil. Inicialmente o Disque Denúncia teve como parceiros os Ministérios da Saúde, do Turismo e o Cecria. Diante da necessidade de fortalecimento do Serviço, em maio de 2004 a Petrobras celebra importante convênio com o Cecria, visando a melhor qualificação do mesmo e o aumento do quadro de pessoal.

A parceria do Ministério da Saúde possibilitou o funcionamento do "call center”, que funcionou no parque de atendimento da ouvidoria do SUS. Já a equipe de análise e recebimento de denúncia funcionava nas dependências da Secretaria Especial dos Direitos Humanos.

Inicialmente funcionando de segunda à sexta, em janeiro de 2006 o Serviço passa a atender também nos finais de semana e feriados. Em 14 de maio desse ano, o Disque Denúncia passa a atender pelo número 100, conseqüência na mudança da empresa de telefonia prestadora de serviço (Embratel para a Brasiltelecom). O anúncio da mudança do número causou uma intensa rejeição e mobilização por parte de alguns segmentos da sociedade civil, sob a alegação de que a mudança acarretaria solução de continuidade, perda de identidade e dificuldades gerais de acesso ao Serviço. A SEDH 
preparou um plano e comunicação visando à divulgação do novo número, no bojo da mobilização do dia 18 de maio - Dia Nacional de Luta contra o Abuso e a Exploração Sexual de Crianças e Adolescentes. Após o dia 14 de maio houve um aumento médio de mais de 300\% no número de ligações, demonstrando a efetividade das ações de divulgação e a facilidade de assimilação do número 100 por parte da população. Importante registrar que o antigo número - 0800990500 - continuou recebendo ligações por mais de seis meses, quando então foi desativado.

O gráfico a seguir demonstra o impacto da mudança do número do Serviço a partir do dia 14 de maio de 2006.

Gráfico 1. Evolução das Denúncias - maio 2006

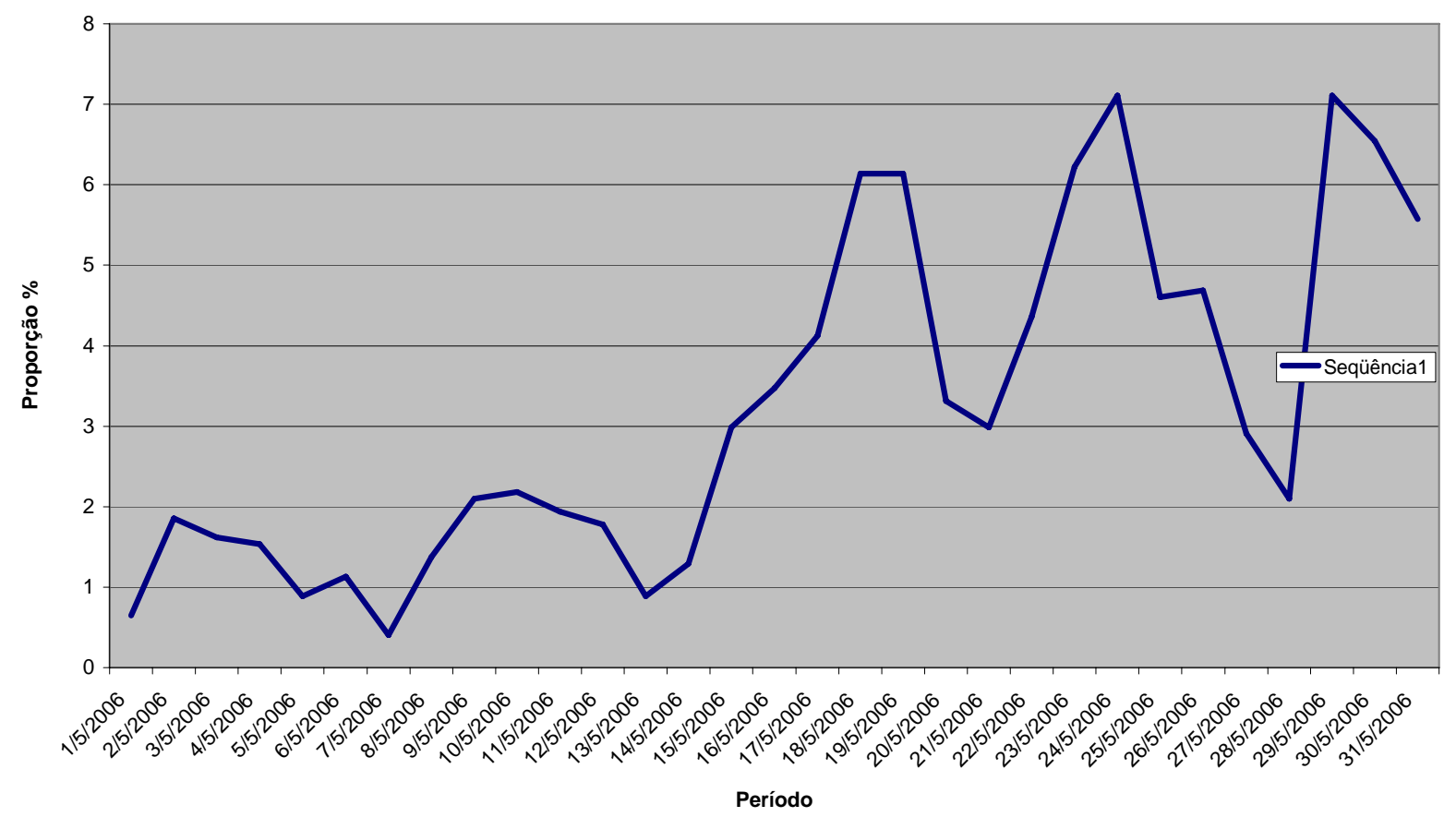

Fonte: DDN - 100/Secretaria Especial dos Direitos Humanos/PR

Outra importante mudança se deu em outubro do mesmo ano, quando as instalações da Ouvidoria da Saúde, local no qual funcionava o "call center” foi alagado após uma forte tempestade ocorrida em Brasília (Marli Batistella - Entrev. 16/11/06). Em menos de 24 horas o atendimento ao usuário passou a funcionar nas dependências da Secretaria Especial dos Direitos Humanos, facilitando a supervisão e o funcionamento do parque de atendimento, bem como conferindo mais unidade ao serviço, uma vez que ficam mais próximas as equipes de atendimento, do encaminhamento das denúncias e da análise dos dados. 
Ainda em 2006, visando internalizar definitivamente o Serviço nas políticas públicas do Governo Federal, durante a revisão do Plano Plurianual (PPA) 2004/2007 foi incluída a ação orçamentária “Apoio ao Disque Denúncia de Abuso e Exploração Sexual de Crianças e Adolescentes” no Programa 0073 - Combate ao Abuso e à Exploração Sexual de Crianças e Adolescentes. A atual elaboração do PPA 2008/2011 também prioriza o fortalecimento do DDN-100 em Programa multissetorial.

\subsubsection{Gestão e Estrutura do Serviço}

\subsubsection{Gestão}

A gestão do DDN-100 é tripartite, com funções e atribuições compartilhadas e definidas entre o Cecria e a Petrobras e a SEDH/PR, por meio da Subsecretaria de Promoção dos Direitos da Criança e do Adolescente, tendo como principal apoiador a Petrobras, órgão financiador de parte das ações desenvolvidas pelo Serviço. (Karina Figueiredo - Entrev. 22/11/06).

As principais atribuições do Cecria estão ligadas à gestão de pessoal dos diversos níveis e ao suporte técnico e metodológico. A capacitação inicial e continuada da equipe é responsabilidade do Cecria, bem como outras importantes atividades a exemplo do suporte psicológico disponibilizado principalmente para o pessoal do Parque de Atendimento.

Por meio de convênio firmado entre a Petrobras e o Cecria, tendo a SEDH como interveniente, foi possível a contratação de pessoal que dá suporte à execução das mais diversas atividades, o desenvolvimento e o constante aprimoramento de sistema informatizado de registro, armazenamento, análise e tratamento de dados, bem como a assistência técnica ao software desenvolvido para a informatização do Serviço. (Wilson Santarosa - Entrev. 13/07/06).

A SEDH é responsável pela coordenação geral e política do DDN-100. A coordenação do Programa de Combate ao Abuso e à Exploração Sexual atua como gerente do Serviço, na área de planejamento, execução e avaliação, em parceria com o Cecria.

Muitas das contra-partidas assumidas no convênio com a Petrobras são assumidas pela SEDH, tais como: implementação do Sistema de Acompanhamento Online das Denúncias nas diversas portas de entrada estabelecidas, a realização de 
seminários nacionais, o estudo qualitativo da base de dados, o desenvolvimento de campanhas nacionais de divulgação e mobilização, a infra-estrutura física e de informática, o suporte de telefonia dentre outras.

A Petrobras, além de repassar os recursos financeiros ao Cecria, divulga o número 100 diretamente em suas atividades, bem como em sua cadeia produtiva, junto aos seus principais parceiros. Um bom exemplo de divulgação sob a responsabilidade da Petrobras se dá por meio do Programa Siga Bem Caminhoneiro, por meio da inserção do quadro Siga Bem Criança. O Programa vai ao ar todos os domingos a partir das 8h30 no SBT. É possível verificar a existência de picos de ligação todos os domingos pela manhã, fato que comprova a eficácia da divulgação por este veículo de comunicação. O DDN - 100 também é divulgado durante as caravanas do Siga Bem Caminhoneiro que percorrem muitos estados brasileiros todos os anos. (Wilson Santarosa - Entrev. 13/07/06).

Os recursos da Petrobras são oriundos da Área de Comunicação e Responsabilidade Social da empresa. Diante da visibilidade nacional do DDN-100, torna-se importante para empresa associar o Serviço ao seu balanço social.

Ao todo, foram firmados até o momento três convênios com a Petrobras visando dá suporte ao funcionamento do DDN-100: o primeiro, assinado em 18 de maio de 2004, possibilitou o repasse de R $\mathbf{( 8 2 5 . 6 8 4 , 0 0 ) ; ~ o ~ s e g u n d o , ~ a s s i n a d o ~ e m ~} 30$ de novembro de 2005, repassou o montante de R\$ (1.629.265,00). Em maio de 2007, o convênio firmado com o Cecria repassará o valor de R $\$(2.679 .865,00)$ significando um aumento de 60\% em ralação ao valor repassado pelo segundo convênio. O substancial aumento do valor do convênio está relacionado à previsão do aumento da equipe, devido ao aumento das ligações e de outras demandas apresentadas a partir do ano de 2006; e a mudança da modalidade de contratação da equipe do Parque de Atendimento de estagiários para CLT, o que acarreta um aumento na carga de obrigações trabalhistas, mas garante uma maior permanência dos membros e de uma equipe muito capacitada.

Importante destacar que a Petrobras assumiu o tema de enfrentamento da violência sexual em várias outras ações desenvolvidas pela empresa, como já descrito, por meio do trabalho desenvolvido junto aos trabalhadores do transporte, postos de gasolina da rede BR de distribuição de combustíveis, postos de gasolina etc. (Wilson Santarosa - Entrev. 13/07/06). 


\subsubsection{Estrutura}

O DDN-100 encontra-se estruturado em três níveis técnicos: o Nível 1, responsável pelo recebimento e registro da denúncia; o Nível 2, responsável pela triagem/análise do conteúdo, pelo encaminhamento e pelo acompanhamento da denúncia; e o Nível 3, responsável pelo tratamento dos dados de telefonia e pela análise e tratamento estatístico da base de dados.

\subsection{Nível 1 - Teleatendimento}

O principal objetivo do teleatendimento é o de atender gratuitamente a população brasileira, prestando informações, recebendo e registrando denúncias de violência contra crianças e adolescentes e realizando orientações e encaminhamentos. (Josemarrie Siqueira - Entrev. 29/01/07).

É garantido o anonimato da denúncia e o encaminhamento em no máximo 24 h. As classificadas como urgentes são encaminhadas de imediato. Após 15 dias de registro da denúncia o usuário passa a acompanhar as providências adotadas pelo serviço com relação ao encaminhamento para os órgãos de responsabilização e defesa, por meio de número de protocolo fornecido durante o atendimento.

O teleatendimento ao usuário utiliza roteiro padrão de atendimento em sistema informatizado, no qual as denúncias são registradas em ambiente web com ferramenta de segurança e restrição de acesso, para tratamento e encaminhamento imediato ao Nível 2.

O sistema informatizado prevê o registro de dados sobre a denúncia em cinco diferentes telas:

1. Informações da(s) Vítima(s);

2. do(s) Suspeitos;

3. Relato da Denúncia;

4. Informações do Denunciante e;

5. Outras Informações: sobre envolvimento da(s) vítimas e/ou suspeito(s) com uso de drogas; sobre vítima(s) ser pessoa com deficiência; sobre Conselhos Tutelares, dentre outras. 
A imagem abaixo representa uma das telas do sistema informatizado de registro da denúncia, na qual pode ser observado a referência para a sondagem.

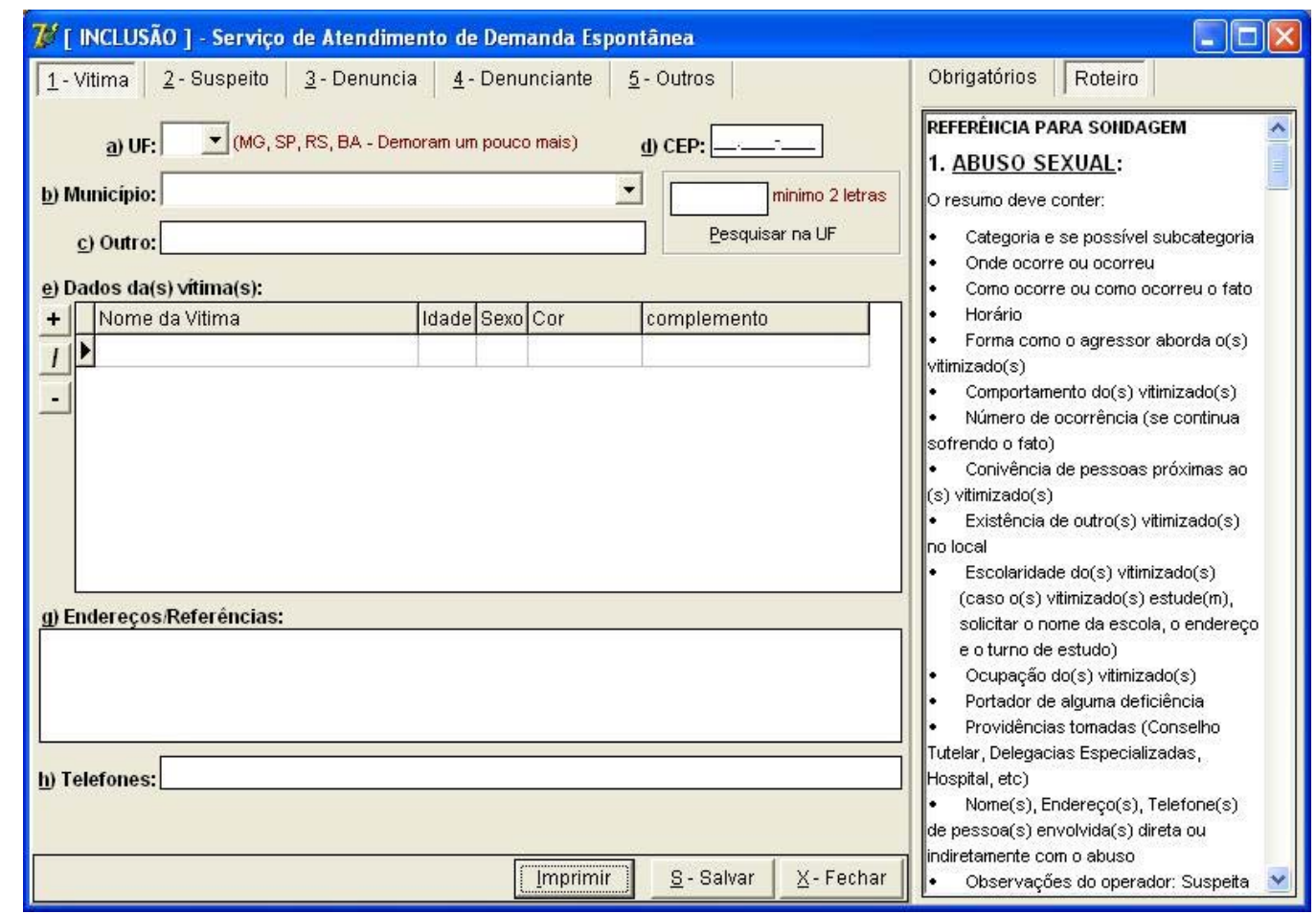

Fonte: DDN - 100/Secretaria Especial dos Direitos Humanos/PR

Uma nova modalidade de atendimento está sendo iniciada, chamada de Escuta Especializada, destinada aos casos onde o usuário é a própria vítima; alega ser o agressor (a exemplo de pedófilos); e nos casos de "trotes recorrentes". Este atendimento é de responsabilidade dos assistentes de monitoria, especialmente capacitados para este fim. Importante destacar que o roteiro de atendimento foi totalmente adequado à esses tipos de situações.

A capacitação dos teleoperadores é um processo permanente, direcionada ao aprofundamento da temática e à qualificação da sondagem no atendimento ao usuário.

No Nível 1 trabalham atualmente 32 teleoperadores, 5 monitores e três assistentes de monitoria, divididos em três turnos de 6 horas, supervisionados por um especialista no funcionamento de parque de atendimento, com conhecimento sobre a temática . A partir de junho de 2007 a equipe passará a contar com 52 teleoperadores, 6 monitores, 3 assistentes de monitoria e 1 supervisor. 


\subsection{Nível 2 - Análise e Encaminhamento da Denúncia}

O Nível 2 tem como atribuição preceder a triagem, categorização, definição do melhor encaminhamento da denúncia, de acordo com a sua natureza, encaminhando-a para os órgãos de responsabilização e defesa. Cabe, ainda ao Nível 2, a alimentação do sistema informatizado sobre os encaminhamentos efetuados das respostas recebidas dos órgãos competentes acerca das providências adotadas para acompanhamento e informação ao usuário. (Marli Batistella - Entrev. 16/11/06)

As denúncias registradas pelo Nível 1 são imediatamente acessadas pelo Nível 2 por meio de um ambiente web. A consulta só é possível com a inserção de senha de acesso.

A tela a seguir demonstra uma das telas visualizada pela equipe do Nível 2.

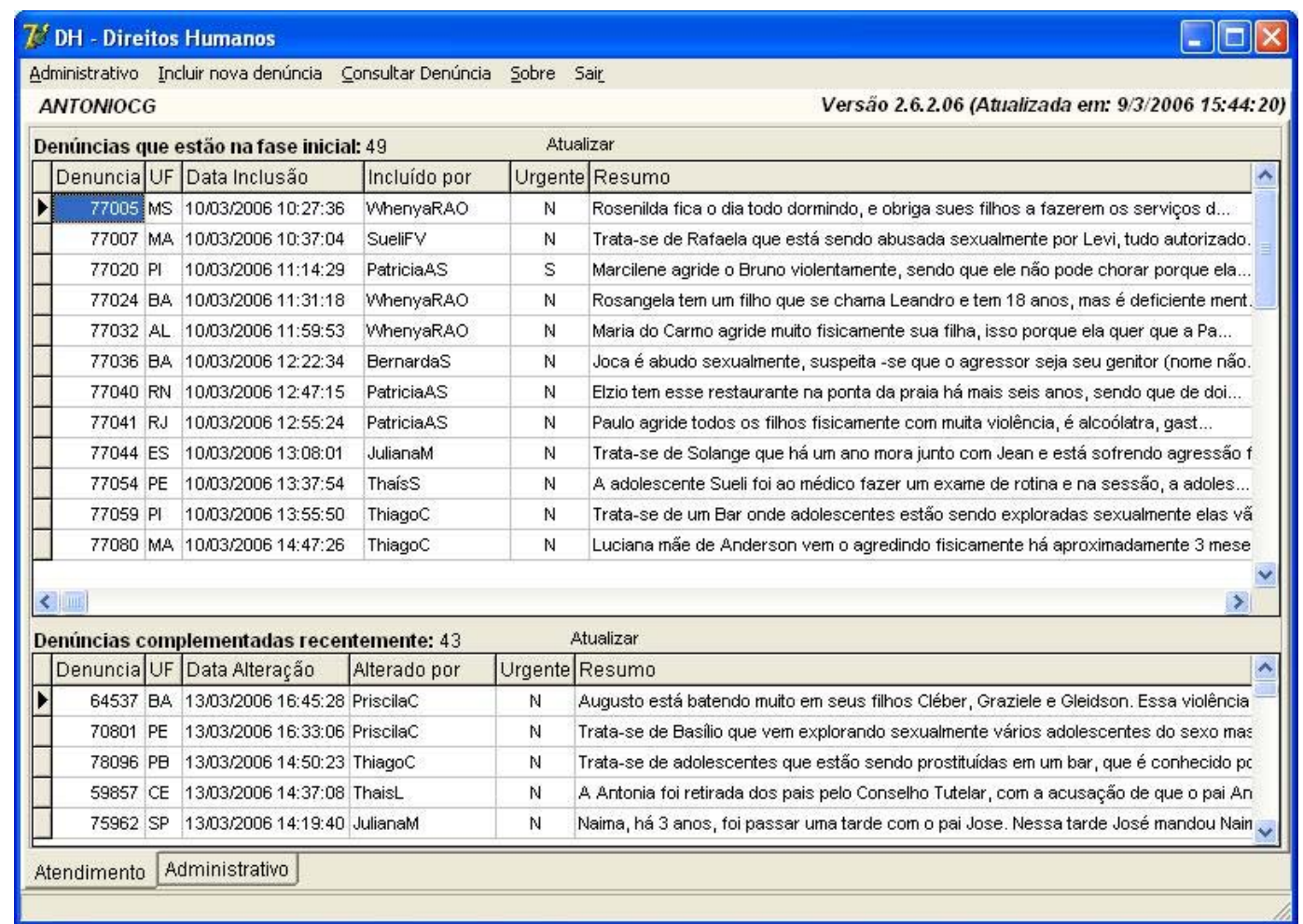

Fonte: DDN - 100/Secretaria Especial dos Direitos Humanos/PR

O Serviço utiliza critérios para a classificação das denúncias que norteiam a forma do seu encaminhamento. Para tanto, são classificadas em Denúncias Urgentes e Denúncias Diferenciadas. As Diferenciadas são aquelas que contém alegações e/ou conteúdos com implicantes de gravidade e requerem maior urgência no 
encaminhamento, e/ou que contenham aspectos considerados peculiares quanto ao tratamento das mesmas.

São sete os critérios para o encaminhamento das denúncias. Os três primeiros são de encaminhamento urgente, via fax e/ou e-mail. Importante destacar que pode ocorrer a identificação de mais de um critério numa denúncia.

\section{- Critério de Identificação 1 - Urgente}

- Risco iminente: quando a denúncia anuncia um acontecimento grave e iminente, a partir de indícios e/ou alegação objetiva.

\section{- Critério de Identificação 2 - Urgente}

- Situação denunciada indica nível de agressão intensa e/ou freqüente.

Procedimento 1 e 2: Denúncia segue por fax para o órgão receptor com maior competência para lidar de imediato com a mesma; preferencialmente busca-se o contato telefônico prévio para apresentação do caso.

\section{- Critério de Identificação 3 - Urgente}

- Alegações informando o paradeiro de crianças e/ou adolescentes desaparecidos.

Denúncia segue por e-mail e/ou fax para a ReDesap - Rede Nacional de Identificação e Localização de Crianças e Adolescentes Desaparecidos.

\section{- Critério de Identificação 4 - Diferenciada}

- Situação com indícios de tráfico de seres humanos (pessoas adultas e/ou crianças e/ou adolescentes).

Procedimento: Denúncia segue por fax e /ou e-mail para a Divisão de Direitos Humanos/DPF/MJ e para o Ministério Público Federal, com cópia para a Secretaria Nacional de Justiça, para conhecimento. 


\section{- Critério de Identificação 5 - Diferenciada}

- Idade da vítima: criança pequena, até 06 anos de idade.

A denúncia segue para o Conselho Tutelar da localidade e para o Ministério Público do Estado por meio de Ofício. Sendo urgente, a denúncia segue por fax para os órgãos com maior competência para lidar com os primeiros encaminhamentos.

Preferencialmente é feito contato telefônico prévio.

\section{- Critério de Identificação 6 - Diferenciada}

- Situações com envolvimento de autoridades públicas.

Denúncia segue para a instância superior do órgão do suspeito (ou para o Ministério Público incumbido de promover a ação penal competente), e/ ou sua Corregedoria, Ministério Público, Judiciário, Secretaria de Segurança Pública, Departamento da Polícia Federal (DPF) etc.

Situações com envolvimento de autoridades religiosas e/ou pessoas influentes na localidade.

Denúncia segue para o órgão superior do Ministério Público Estadual ou Federal, conforme o caso, e/ou para a Polícia Federal.

\section{- Critério de Identificação 7 - Diferenciada}

Denúncias de sites de pornografia e pedofilia pela Internet. Denúncia segue por fax e/ou e-mail para a Safernet $^{9}$, com cópia para a Divisão de Direitos Humanos da Polícia Federal.

A tabela abaixo representa os marcos legais para encaminhamento das notificações/denúncias. Cada órgão está relacionado com uma ou mais legislações.

Tabela 2. Base Legal de Encaminhamentos aos Principais Órgãos Receptores de Denúncias

MPF- Ministério Público Federal

Promoção da ação penal nos crimes de competência da Justiça Federal, ex.: tráfico internacional de seres humanos, trabalho escravo e alguns crimes contra os direitos humanos passíveis de federalização; arts. 128, I, "a", e 129, I, ambos da CF; art. 201, ECA

\footnotetext{
${ }^{9}$ Organização não governamental especializada em rastreamento e preparação da noticia criminis, trabalho que facilita a investigação da polícia.
} 
MPE- Ministério Público Estadual

Promoção da ação penal nos crimes de violência, violência sexual e exploração sexual de crianças e adolescentes de competência da justiça estadual; promoção de ações civis, ex.: afastamento cautelar do agressor da moradia comum; suspensão ou destituição familiar; ação civil ex delicto (reparação de danos - materiais e/ou morais decorrentes da violência).

Conselho Tutelar

Atender as crianças e adolescentes e famílias em situação de violência, violência sexual e exploração sexual, aplicando as medidas extrajudiciais pertinentes e fazendo os encaminhamentos necessários.

\section{Polícia Civil e Especializadas}

Apuração de crimes de violência, violência sexual e exploração sexual de crianças e adolescentes de competência da Justiça Estadual; pode envolver prisões, buscas e apreensões; tomadas de depoimentos, exames periciais,

arts. 128, II e 129 da CF; arts. 95, 141 e 201 do ECA

ReDesap - Rede de Localização e Investigação de Crianças e Adolescentes Desaparecidos Primeiras providências para ações articuladas de identificação e localização de crianças e adolescentes.

\section{Polícia Federal}

Interestadual ou internacional que exijam repressão uniforme, ex.: tráfico internacional de seres humanos, trabalho escravo e alguns crimes contra os direitos humanos passíveis de federalização; crimes cibernéticos.

\section{Polícia Rodoviária Federal /Polícia Rodoviária}

\section{Estadual /Polícia Militar}

Patrulhamento ostensivo das vias federais (PRF), das vias estaduais (PRE) e policiamento ostensivo de ruas e logradouros públicos e preservação da ordem pública (PM)

Centros de Defesa de Crianças e Adolescentes Proteção Jurídico Social para crianças e adolescentes e famílias em situação de violência, violência sexual e exploração sexual. Envolve não só a orientação jurídica, mas também a promoção e o acompanhamento de ações judiciais relacionadas à temática.

Fonte: Elaboração Própria

A próxima ilustração demonstra os caminhos da denúncia on-line ${ }^{10}$ em cada etapa, desde o primeiro contato com os teleoperadores.

Tabela 3. Encaminhamento e Acompanhamento on-line das Denúncias

ETAPA 1 - Experimental no DF e em SP ETAPA 2 - por metas no país;

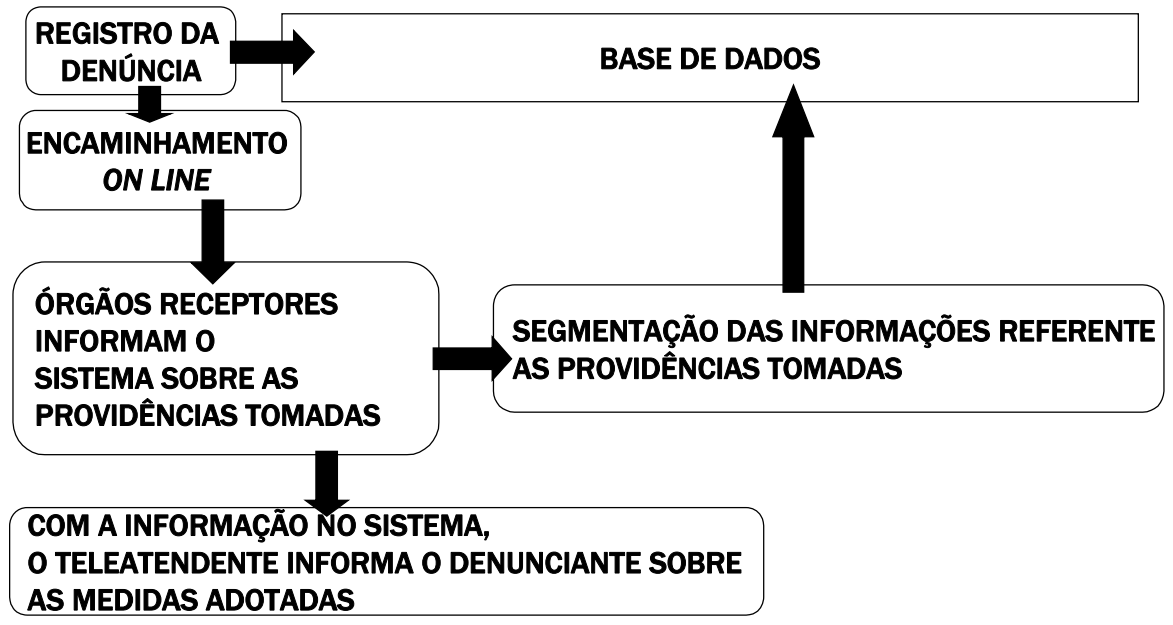

\footnotetext{
${ }^{10}$ Em cada Unidade da Federação terá um órgão de referência que abrigará o sistema on-line e para o qual
} serão encaminhadas as denúncias. 


\subsection{Nível 3 - Análise e tratamento de dados}

O Nível 3 é responsável pelo tratamento estatístico do banco de dados e dos relatórios de telefonia do serviço.Em 2006 foi instalada ferramenta informatizada de extração de dados, facilitando a elaboração de relatórios com defasagem de menos de 24 horas.Os dados são utilizados em boletins bimestrais e enviados para os órgãos cadastrados. Uma demanda crescente está relacionada à elaboração de trabalhos acadêmicos, principalmente alunos da área de ciências humanas. Freqüentemente o serviço é demandado pela imprensa e por outros órgãos dos Governos Federal e Estadual.

Os relatórios de telefonia são fornecidos pela empresa prestadora do serviço telefônico e informam para o DDN-100 dados relacionados a todas as ligações que passam pela Unidade de Resposta Automática (bilhetagem), ou seja, informações sobre o comportamento das ligações que são direcionadas para o atendimento humano e eletrônico. Estas informações são essenciais para dimensionar, por exemplo, o número de operadores necessários por cada turno, a demanda reprimida, o horário de maior acesso etc.

\subsubsection{Dados do DDN - 100}

As tabelas a seguir demonstram alguns dados retirados de uma amostra de 6.619 atendimentos e denúncias da base de dados do DDN - 100 .

Tabela 4. Total de atendimentos recebidos pelos teleatendentes no Período de 21/02/2005 à 11/03/2006

\begin{tabular}{|c|c|}
\hline \multicolumn{2}{|c|}{ Período de 21/02/2005 à 11/03/2006 } \\
\hline Tipo & Quantidade \\
\hline Sugestões ao serviço & 34 \\
\hline Criança e Adolescentes Desaparecidos & 42 \\
\hline Elogios & 49 \\
\hline Reclamações & 202 \\
\hline Solicitação mat. Informativo & 208 \\
\hline Denúncia Reduzida (sites pornografia pela Internet) & 266 \\
\hline Ligação não pertinente & 1602 \\
\hline Denúncia & 6353 \\
\hline Orientações & 9065 \\
\hline Trote - Adulto & 9582 \\
\hline Trote - Criança & 10483 \\
\hline Ligação Muda/Interrompida & 29452 \\
\hline Total & 67338 \\
\hline Total de Denúncias & 6619 \\
\hline
\end{tabular}

Fonte: DDN - 100/Secretaria Especial dos Direitos Humanos/PR 
Conforme demonstrado na tabela anterior, das 67.338 ligações direcionadas no período para o atendimento humano, 43,7\% resultam em ligações mudas ou interrompidas. Os trotes representam em média 29,8\%. Do total de ligações, apenas 9\% resultam em denúncias registradas no sistema.

Tabela 5. Total de denúncias por categorias OBS: Uma denúncia pode ter mais de uma categoria e mais de uma vítima

\begin{tabular}{|c|c|c|c|}
\hline \multirow[t]{2}{*}{ Categoria } & \multirow[t]{2}{*}{ Denúncia } & \multicolumn{2}{|c|}{ Sexo } \\
\hline & & Fem & Masc \\
\hline Crianças e Adolescentes Desaparecidos & 51 & 13 & 7 \\
\hline Violência Psicológica & 995 & 953 & 827 \\
\hline Exploração Sexual & 1770 & 2267 & 469 \\
\hline Abuso Sexual & 1897 & 2063 & 727 \\
\hline Negligência & 2137 & 2285 & 2060 \\
\hline Violência Física & 3277 & 2895 & 2827 \\
\hline
\end{tabular}

Fonte: DDN - 100/Secretaria Especial dos Direitos Humanos/PR

Das denúncias registradas na amostra apresentada, 36,4\% são referentes à violência sexual, 42,4\% à violência física e psicológica, e 21,2\% à negligência. Nos casos de violência sexual predominam vítimas do sexo feminino.

Considerando as denúncias recebidas, o Serviço apresenta a seguinte média de denúncias/dia por ano:

- Média de denúncias/dia em 2003: 12 denúncias/dia

- Média de denúncias/dia em 2004: 10 denúncias/dia

- Média de denúncias/dia em 2005: 14 denúncias/dia

- Média de denúncias/dia em 2006: 37 denúncias/dia

- Média de denúncias/dia em 2007 (até 10 de maio): 42 denúncias/dia 
Considerando os atendimentos realizados diariamente, temos a seguinte média de atendimento humano/dia por ano:

Obs: A partir de 2005, toda vez que o teleoperador presta o serviço de atendimento, seja ou não registrada uma denúncia, este serviço é registrados como atendimento humano e categorizado segundo o tipo de atendimento.

- Média de atendimentos/dia em 2003: 12 atendimentos/dia

- Média de atendimentos/dia em 2004: 10 atendimentos/dia

- Média de atendimentos/dia em 2005: 111 atendimentos/dia

- Média de atendimentos/dia em 2006: 1.368 atendimentos/dia

- Média de atendimento/dia em 2007 (até 10 de março): 2.482 atendimentos/dia

O gráfico abaixo apresenta a evolução do número de denúncias de 2003 a 2006.

Gráfico 2. Disque Denúncia - 100

Total de Denúncias Brasil por ano

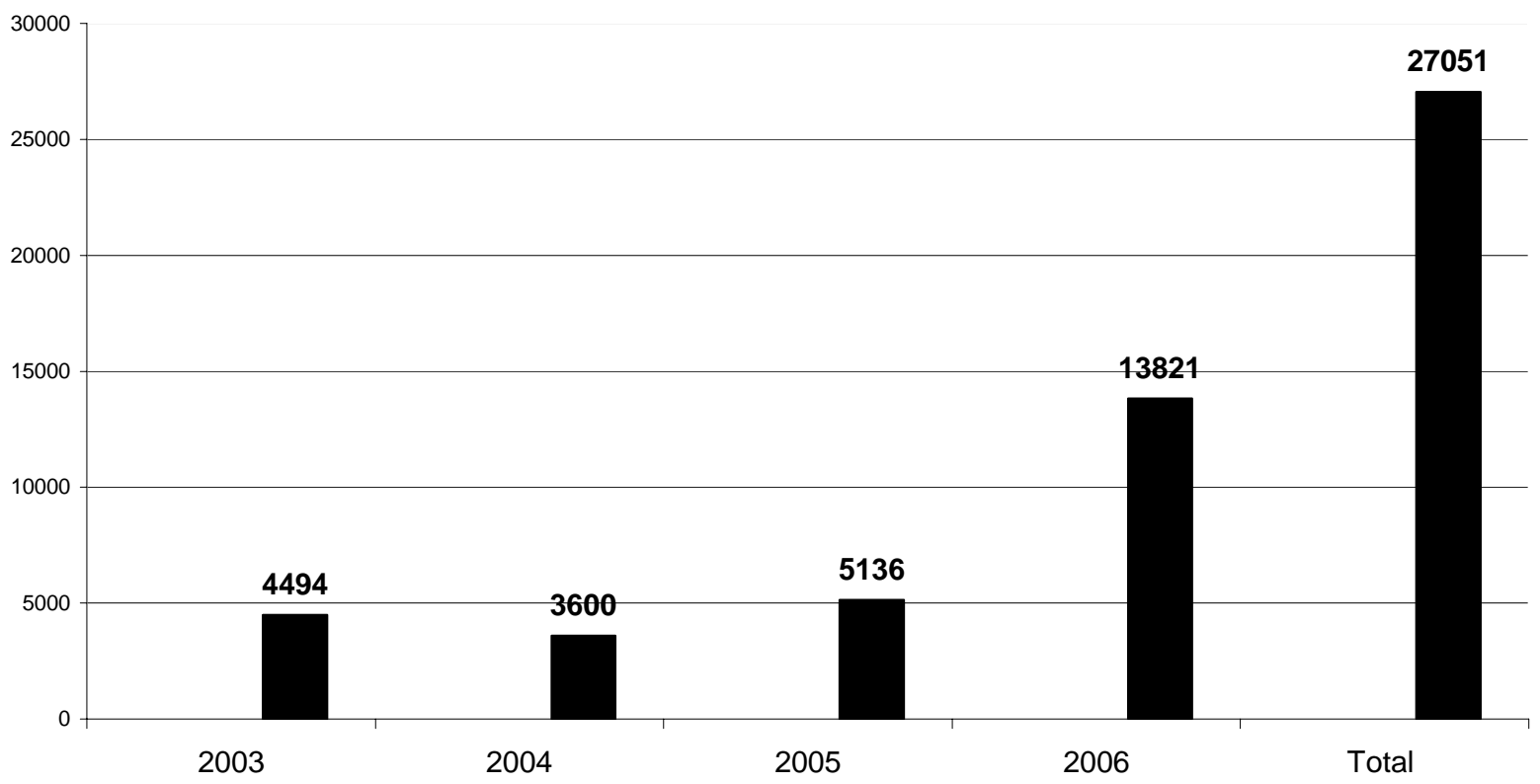

Fonte: DDN - 100/Secretaria Especial dos Direitos Humanos/PR

Cabe destacar que até 2004 eram registradas apenas denúncias de violência sexual. A partir de 2005 o Serviço passa a receber e registrar denúncias de outros tipos de violência. Em 2006 observa-se um aumento no número de ligações e do número de denúncias após a mudança do número.

O gráfico a seguir apresenta o registro dos tipos de violência nas 23.369 denúncias categorizadas (2003 até 20 de março de 2007). As categorias apresentadas 
abaixo ainda são subdivididas e aprofundadas nos tipos específicos de violência, exemplo: a categoria de violência tráfico de pessoas pode ser subdividida em tráfico nacional, tráfico internacional ou não informado.

Gráfico 3. Disque Denúncia - 100

Registros por Categoria de Violência

Brasil 2003 a 20 de março de 2007

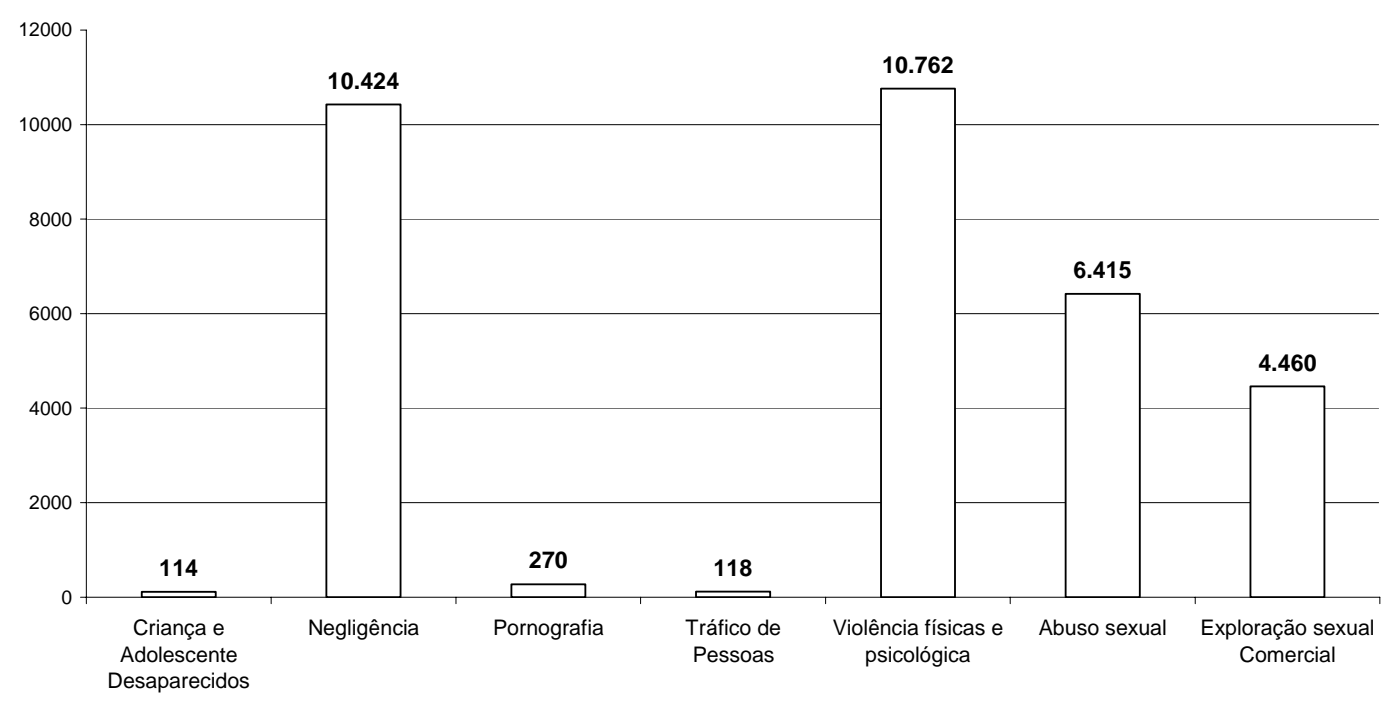

Fonte: DDN - 100/Secretaria Especial dos Direitos Humanos/PR

Das 30.747 denúncias recebidas pelo serviço Disque Denúncia Nacional-100 desde 2003 até 20 de março de 2007, estão categorizadas por tipo de violência, 23.369 delas. Em uma denúncia pode-se ter registrado mais de um tipo de violência sofrida por uma ou mais vítimas. Uma denúncia pode, portanto, envolver inúmeras vítimas e diferentes tipos de violência. Em uma denúncia ainda, podemos ter mais de um suspeito. A base de dados do serviço possibilita categorizar os diferentes tipos de violência contra uma mesma vítima e registrar mais de uma vítima numa mesma denúncia (não são denúncias individualizadas). Portanto, observa-se que o número de denúncias será diferente do total de registros dos tipos de violência.

A tabela a seguir apresenta o total de registro por categoria de violência nas 23.369 denúncias categorizadas (registros de 2003 até 20 de março de 2007) e o total de registros dos tipos de violência, Brasil. 


\begin{tabular}{|c|c|c|}
\hline \multicolumn{3}{|c|}{$\begin{array}{l}\text { Tabela 6. Registros dos Tipos de Violência nas Denúncias Categorizadas } \\
\text { de } 2003 \text { a } 20 \text { de março de } 2007\end{array}$} \\
\hline Categorias & Tipos de Violência & $\begin{array}{l}\text { Total de Registros dos } \\
\text { tipos de violência }\end{array}$ \\
\hline \multicolumn{2}{|c|}{ Crianças e Adolescentes Desaparecidos } & 114 \\
\hline \multirow{5}{*}{$\begin{array}{l}\text { Exploração Sexual } \\
\text { Comercial } \\
4.460 \text { registros }\end{array}$} & Atividade autônoma & 749 \\
\hline & Exploração por terceiros & 3.891 \\
\hline & $\begin{array}{l}\text { Exploração por terceiros em situação de } \\
\text { escravidão }\end{array}$ & 62 \\
\hline & Prostituição & 471 \\
\hline & Turismo sexual & 38 \\
\hline \multicolumn{2}{|l|}{$\begin{array}{l}\text { Negligência } \\
10.424 \text { registros }\end{array}$} & 10.424 \\
\hline \multirow{4}{*}{$\begin{array}{l}\text { Pornografia } \\
270 \text { registros }\end{array}$} & ao vivo & 22 \\
\hline & Impresso & 61 \\
\hline & Internet & 167 \\
\hline & Vídeo & 80 \\
\hline \multirow{3}{*}{$\begin{array}{l}\text { Tráfico } \\
118 \text { registros }\end{array}$} & Internacional & 75 \\
\hline & Nacional & 39 \\
\hline & Não Informado & 9 \\
\hline \multirow{4}{*}{$\begin{array}{l}\text { Violência } \\
10.762 \text { registros }\end{array}$} & Com lesão corporal & 6.758 \\
\hline & Com morte & 95 \\
\hline & Violência física & 9.247 \\
\hline & Violência psicológica & 4.954 \\
\hline $\begin{array}{l}\text { Abuso Sexual } \\
6.415 \text { registros }\end{array}$ & Abuso sexual & 6.415 \\
\hline \multicolumn{2}{|c|}{ Total de denúncias categorizadas - Brasil } & 23.369 \\
\hline
\end{tabular}

Fonte: DDN - 100/Secretaria Especial dos Direitos Humanos/PR 


\subsection{Desafios para a melhoria do DDN - 100}

Segundo a coordenadora do DDN-100, Cristina Albuquerque (Entrev. 15/02/07), os seguintes desafios se impõem visando a melhoria e qualificação do Serviço, os quais serão tratados a seguir.

1. Melhoria da articulação com os órgãos de responsabilização e defesa;

2. Melhoria do tratamento da base de dados;

3. Estabelecimento de estratégias sistemáticas de divulgação dos dados;

4. Garantia de recursos orçamentários oriundos da Fonte do Tesouro, com vistas à sustentabilidade do Serviço;

5. Implantação do sistema de encaminhamento on-line em todas as Unidades da Federação; e

6. Integração aos demais canais de denúncia (serviços estaduais).

\subsubsection{Melhoria da articulação com os órgãos de responsabilização e defesa}

A articulação do Disque Denúncia com os serviços de notificação dos estados (disque denúncias estaduais e municipais) e com os organismos de defesa e responsabilização implica ganhos para a rede de proteção local, além de ser um recurso fundamental para a obtenção de indicadores de responsabilidades, e da efetividade e eficácia das providências tomadas na localidade, visando à resolubilidade das denúncias/notificações. Entretanto, este se constitui no grande desafio a ser enfrentado por todos os atores envolvidos no processo.

Em março de 2006 foi realizado o I Seminário do Disque Denúncia Nacional de Abuso e Exploração Sexual de Crianças e Adolescentes. O encontro reuniu operadores da área de responsabilização e defesa de todo o país, e outros representantes do Sistema de Garantia de Direitos, a exemplo dos Conselhos Estaduais dos Direitos da Criança e do Adolescente. Na pauta, temas como nivelamento de conceitos, fluxo das denúncias e integração dos serviços. Está prevista para o final de 2007 a realização do II Seminário do DDN-100.

A Secretaria Especial dos Direitos Humanos mantém acordos de cooperação técnica com os Centros de Apoio Operacional dos Ministérios Públicos Estaduais. Pelo acordo, os Ministérios Públicos se comprometem a informar o encaminhamento dado às denúncias em nível estadual. 


\subsubsection{Melhoria do tratamento da base de dados}

O programa informatizado para extração de dados da base do DDN-100 foi implantado no segundo semestre de 2006. Atualmente o sistema está sendo ajustado para possibilitar a extração em tempo real. Outros ajustes e melhorias estão previstos para 2007, inclusive a contratação de um estatístico com a finalidade de avaliar a consistência dos dados extraídos do sistema e propor alterações para a sua melhoria. A idéia é firmar o Serviço como uma dos subsídios para a elaboração e implementação de políticas públicas. Apesar disso, o cenário atual não é nada favorável. O serviço ainda não tem um sistema de acesso on-line para a sociedade efetuar consultas, alem disso o usuário do Serviço apenas fica com o numero do protocolo, sem saber de maiores detalhes do processo de encaminhamento das denúncias. É evidente que existe avanço nos últimos anos com a informatização do Serviço, isso ajuda a levantar a base de dados mais rapidamente, o que falta é disponibilizar tudo isso a população.

\subsubsection{Estabelecimento de estratégias sistemáticas de divulgação dos dados}

Além do Boletim, o DDN-100 prevê a elaboração de um Plano de Comunicação em 2007, de forma a universalizar as informações e conferir transparência ao Serviço. Hoje, o Serviço não disponibiliza facilmente os dados, sendo esses muitas vezes desatualizados, com erros e as vezes nem são divulgados para a sociedade e instituições. O DDN-100, possibilita dar uma visibilidade maior a questão da violência cometida contra crianças e adolescentes, por isso é fundamental que haja uma maior divogação dos dados para que então a sociedade civil e o Estado possam buscar maneiras de enfrentar esse problema. No Convenio assinado entre a Petrobras e o Serviço não estabelece orçamento fixo para melhoria de distribuição desses dados, visando somente os gastos administrativos e humanos.

\subsubsection{Garantia de recursos orçamentários oriundos da Fonte do Tesouro, com} vistas à sustentabilidade do Serviço

O Serviço Disque Denúncia Nacional de Abuso e Exploração Sexual de Crianças e Adolescentes, apesar de estar em pauta no Plano Plurianual 2007 nº 0073, 
onde apresenta apenas um orçamento no total de cerca de $\mathrm{R} \$ 120.000,00$, hoje não é um programa de responsabilidade somente do governo, dependendo em especial de investimentos da Petrobras, que injeta, como já falado anteriormente, em 2007, cerca de R\$ 2.679.865,00, ou seja, o valor destinado pelo governo não cobre nem 4,5\% do gasto real do DDN-100. Isso gera uma grande dependência do Serviço com a Petrobras, uma empresa, apesar de estatal, não fornece garantia de futuros investimentos no Serviço. Apesar de que existe um significativo aumento nos convênios firmados nos últimos anos com a empresa, o que possibilitou uma ampliação do Serviço. É fundamental que o orçamento seja totalmente da esfera pública, garantindo, em futuros PPAs, a renovação e orçamento necessários à realização de um programa eficiente que atenda cada vez melhor seus objetivos de trabalho. Assim possibilita melhores planejamentos das ações do Serviço e de certa forma garantindo que ele irá funcionar indefinidamente e com recursos.

\subsubsection{Implantação do sistema de encaminhamento on-line em todas as Unidades da Federação}

O sistema on-line, como já falado anteriormente no Estudo, facilita os encaminhamentos da notificação/denúncia, acontece imediatamente sem ter que enviar ofícios demorados e burocráticos. O sistema on-line possibilita a troca rápida de informações entre o DDN-100 e os órgãos envolvidos para apuração da mesma. Dessa forma o Disque, apesar de já estar com o sistema experimental nos estados do Distrito Federal e São Paulo, ainda precisa ampliar de modo significativo para os outros estados, o que torna isso uma meta prioritária do Serviço e uma ação governamental. Caso isso ocorra, a amplitude do Serviço quebrará barreiras e burocracias, facilitando tanto para o próprio Disque, como para os órgãos envolvidos e também para os utilizadores do DDN-100. Ao passo que esse sistema possibilita o retorno das notificações/denúncia provenientes do Disque, assim, além de fortificar a rede de ação do Disque, existe um enorme ganho de informações de um órgão para o outro e o acesso pode ser de qualquer lugar do país, logicamente com certos critérios para isso, como senhas de acesso ou outro sistema seguro. 


\subsubsection{Integração aos demais canais de denúncia (serviços estaduais)}

A necessidade de integração dos diversos canais de denúncia estruturados no país já vem sendo discutida desde 2006. Este assunto será um dos temas do II Seminário do Disque Denúncia Nacional de Abuso e Exploração Sexual de Crianças e Adolescentes. O que determina essa maior integração aos canais de denúncia estaduais são acordos de cooperação técnica firmados através de debates, seminários, encontros reuniões, ou seja, mecanismos que aproximem melhor a realidade estadual e federal. 


\section{Considerações Finais}

Esse estudo constitui significativo instrumento para identificação, caracterização e análise do cenário existente na relação entre conceitos teóricos relativos à violência sexual contra crianças e adolescentes, o marco legal nacional e internacional e o Serviço Disque Denúncia Nacional de Abuso e Violência Sexual de Crianças e Adolescentes. Ao relacionar esses três aspectos, o estudo possibilitou entender o DDN-100 sob uma perspectiva de garantia de direitos.

Ao teorizar a questão da violência sexual, o estudo constatou os distintos aspectos abordados que evidenciam que a ocorrência da violência sexual contra crianças e adolescentes tem uma estreita relação com a construção do modelo de sociedade brasileira e se manifesta principalmente pela forma como o poder é exercido no âmbito familiar e comunitário. Apesar dos diferentes conceitos sobre violência sexual, o estudo aponta a necessidade de enfrentar qualquer forma de abuso ou exploração sexual cometida contra a criança ou adolescente.

Na segunda parte do trabalho, apresenta-se o marco legal referente aos direitos fundamentais da criança e do adolescente, entendendo que os direitos da criança e do adolescente, definidos em declarações e convenções internacionais, nas legislações nacionais, no que concerne a garantia de direitos, de integridade psicológica, ao respeito, à dignidade e ao direito ao processo de desenvolvimento físico, psicológico e sexual de crianças e adolescentes vitimas de abuso ou exploração sexual.

Relata-se a importância do processo que culminou com a criação do Estatuto da Criança e do Adolescente em resposta à falência do Código de Menores. O Estatuto, apesar de ainda ter um longo caminho até sua concretização na prática, apresenta uma visão inovadora frente às legislações antigas, colocando a criança e o adolescente como sujeitos de direito, e não como um objeto, assim como era tratado no Código de Menores. Na prática, isso representa uma mudança na criação de políticas, ações, serviços públicos referentes a criança e adolescente. Nesse sentido a sociedade passa a ter papel fundamental no controle e criação das ações públicas, garantindo assim o que diz no ECA e nas demais legislações, sejam nacionais e internacionais.

Na ultima parte do estudo foi analisado o Serviço Disque Denúncia Nacional de Abuso e Exploração Sexual de Crianças e Adolescentes (DDN-100). Foi possível verificar minuciosamente todas as ações desenvolvidas pelo Serviço, evidenciar seu surgimento através de demandas populares. Definiu-se os sujeitos envolvidos na gestão, 
a frente a SEDH, Cecria e Petrobras. Foram entrevistadas pessoas chaves do DDN-100, que colaboraram com informações sobre o Serviço, sua gestão, organização, encaminhamento da denúncia, tratamento e publicação dos dados que dão visibilidade à questão da violação de direitos contra a criança e adolescente.

Frente aos dados recolhidos em diferentes instituições e nas entrevistas, foi possível traçar um perfil do Disque Denúncia Nacional. Desde a criação do Serviço até hoje, é notadamente visível que existe um crescente investimento orçamentário, tecnológico e humano que geraram um melhor atendimento aos usuários, definição de fluxos das denúncias, melhor tratamento dos dados e disponibilidade dos mesmos à sociedade. Porém, mesmo tendo grandes avanços, o DDN-100 apresenta diversos desafios, tais como a dependência dos recursos da Petrobras, o que dificulta o planejamento das ações a longo prazo, já que a Petrobras não tem obrigação de financiar o Serviço. Também é necessário uma maior articulação com os órgãos de responsabilização e defesa, já que isso se traduz na resolubilidade do Serviço , pois de nada adianta a população denunciar se não existir efetividade e agilidade desses órgãos. Por isso a necessidade de constante aproximação com diversos órgãos para realizar os acordos de cooperação técnica e o estabelecimento de fluxos de denúncia. O Disque precisa também melhorar o tratamento da base de dados, estabelecer estratégias sistemáticas de divulgação dos mesmos, implementar o sistema de encaminhamento online em todas as Unidades da Federação, garantindo assim maior velocidade nos encaminhamentos das denúncias. Por fim, viabilizar uma maior integração com os demais canais de denúncia (serviços estaduais), visando evitar a duplicidade de ações. Este estudo possibilita e abre portas para novas pesquisas referentes a temática colocada. O tema deve ser colocado como prioritário nas análises futuras para que com isso seja ampliado o debate das questões levantadas e possibilitar que o DDN-100 seja cada vez considerado não mais como um serviço, ação, e sim como uma política publica com verba prioritariamente pública. 


\section{$\underline{\text { Referências Bibliográficas }}$}

AZEVEDO, M. ${ }^{\text {a }}$ \& Guerra, V. N. A. Violência de pais contra filhos: Procuram-se vitimas. São Paulo: Cortez, 1984.

. Crianças vitimizadas: A Síndrome do Pequeno Poder. São Paulo: Iglu, ed.,2000.

BRASIL. Constituição da República Federativa do Brasil, 1988

. Lei 8.069/90. Estatuto da Criança e do Adolescente.

Código de Menores. São Paulo, Forense,1982.

CALMON DE PASSOS, J.J. Direito, poder, justiça e processo. Julgando os que nos julgam. Rio de Janeiro, Revista Forense, 1999.

CFESS, ABEPSS, CEAD, UnB. Intervenção e pesquisa em Serviço Social. In: Capacitação em Serviço Social e Política Social. Módulo 05. Brasília. DF: Universidade de Brasília, 2001.

CHAUÍ, Marilena. Participação do debate sobre mulher e violência. Em perspectivas Antropológicas da Mulher. Rio de Janeiro: Zahar, 1985.

COSTA JÚNIOR, Paulo José da. Curso de direito penal. São Paulo: Saraiva, 1992.

FALEIROS, E. Repensando os conceitos de violência, abuso e exploração sexual de crianças e adolescentes. Brasília: Thesaurused.,2000.

FALEIROS, V.P. A violência sexual contra crianças e adolescentes e a construção de indicadores: A crítica do poder, da desigualdade e do imaginário in LEAL, M. F.P. \& CÉSAR, M.A. (Org.). Indicadores de violência intra-familiar e exploração sexual 
comercial de crianças e adolescentes. BRASÍLIA:Cecria, Ministério da Justiça e CESE, 1998.

FALEIROS, Vicente de Paula/FALEIROS, Eva Terezinha.S.(coordenadores). Circuito e Curtos-Circuitos: atendimento, defesa e responsabilização do abuso sexual contra crianças e adolescentes no Distrito Federal. São Paulo: Veras Editora, 2001.

FOUCAULT, Michel. Os anormais. São Paulo: Martins Fontes, 2002.

Fundo das Nações Unidas para Infância - UNICEF - Brasil. Relatório de Situação da adolescência Brasileira: 2002.

GOMES DA COSTA, Antônio Carlos. De menor a cidadão. Brasília, Ed. Fundação CBIA, 1990.

HAZEAU. Direitos sexuais da criança e do adolescente: leitura social e jurídica: exploração sexual e violência sexual. Belém. S.d. 1996.

LEAL, Maria Lúcia P. A construção teórica sobre a violência sexual. In: Rompendo o Silêncio. São Luiz: CEDECA, Centro de Defesa Pe. Marcos Posserini, Procuradoria Geral da Justiça, 1997.

As ONG's no Enfrentamento da Exploração e Abuso Sexual de Crianças e Adolescentes. MIMEO, CECRIA, Brasília, 1997.

Exploração Sexual Comercial de Meninos, Meninas e de Adolescentes na América Latina e Caribe: relatório final - Brasil. Brasília: CECRIA, 2000.

LOCKE, John. Segundo Tratado Sobre o Governo Civil. São Paulo: Nova Cultural, 1978.

MINAYO, Maria Cecília de Souza (Org.). Pesquisa social: Teoria, método e criatividade. 21.ed. Petrópolis, RJ: Vozes, 1994. 
MORIN, Edgar. Os setes saberes necessários à educação do futuro. 9. ed. São Paulo: Cortez, 2004.

Secretaria Especial dos Direitos Humanos/ Presidência da República.

UNICEF et. al. Congresso mundial contra a exploração sexual comercial de crianças e adolescentes. S.l. S.d. 


\section{$\underline{\text { Anexos }}$ \\ Termo de Consentimento Livre e Esclarecido}

$\mathrm{Eu}$, declaro que fui informado(a) e compreendi que a presente pesquisa tem como contribuir para melhor conhecimento a cerca do Serviço Disque Denúncia Nacional de Abuso e Exploração Sexual de Crianças e Adolescentes (DDN-100). Sendo assim, decidi voluntariamente participar dessa pesquisa sob responsabilidade da prof $^{\mathrm{a}}$. $\mathrm{Dr}^{\mathrm{a}}$. Maria Lucia Pinto Leal (Endereço: Departamento de Serviço Social, Universidade de Brasília, ICC Centro, Asa Norte, CEP 70.910-900 Brasília/DF; Telefone: (61-3307-2290).

Terei ainda o direito de desistir de participar desta pesquisa a qualquer momento e diante de tal decisão não haverá nenhuma ônus para minha pessoa.

O termo foi assinado por mim e pela pesquisadora

Brasília,_de____de 2007.

Assinatura da pessoa entrevistada

Assinatura do pesquisador 
Roteiro de entrevista

Bloco 1

1- Qual sua visão sobre a questão do abuso e da exploração sexual contra crianças e adolescentes?

2- Como sua concepção é vista pelos outros profissionais?

3- Como você acha que deve ser enfrentado essa questão?

Bloco 2

1- O que representa o Disque Denúncia Nacional de Abuso e Exploração Sexual de Crianças e Adolescentes para você?

2- Qual sua responsabilidade no Serviço?

3- Quais os Avanços do Serviço nos últimos anos?

4- Quais os desafios e problemas a serem enfrentados pelo Disque Denúncia?

5- Qual a importância da visibilidade do Serviço?

6- Qual a importância do controle social do serviço? 
Foto do tele operador (Call Center, DDN-100/SEDH)) utilizando uma das telas mostradas na pesquisa.

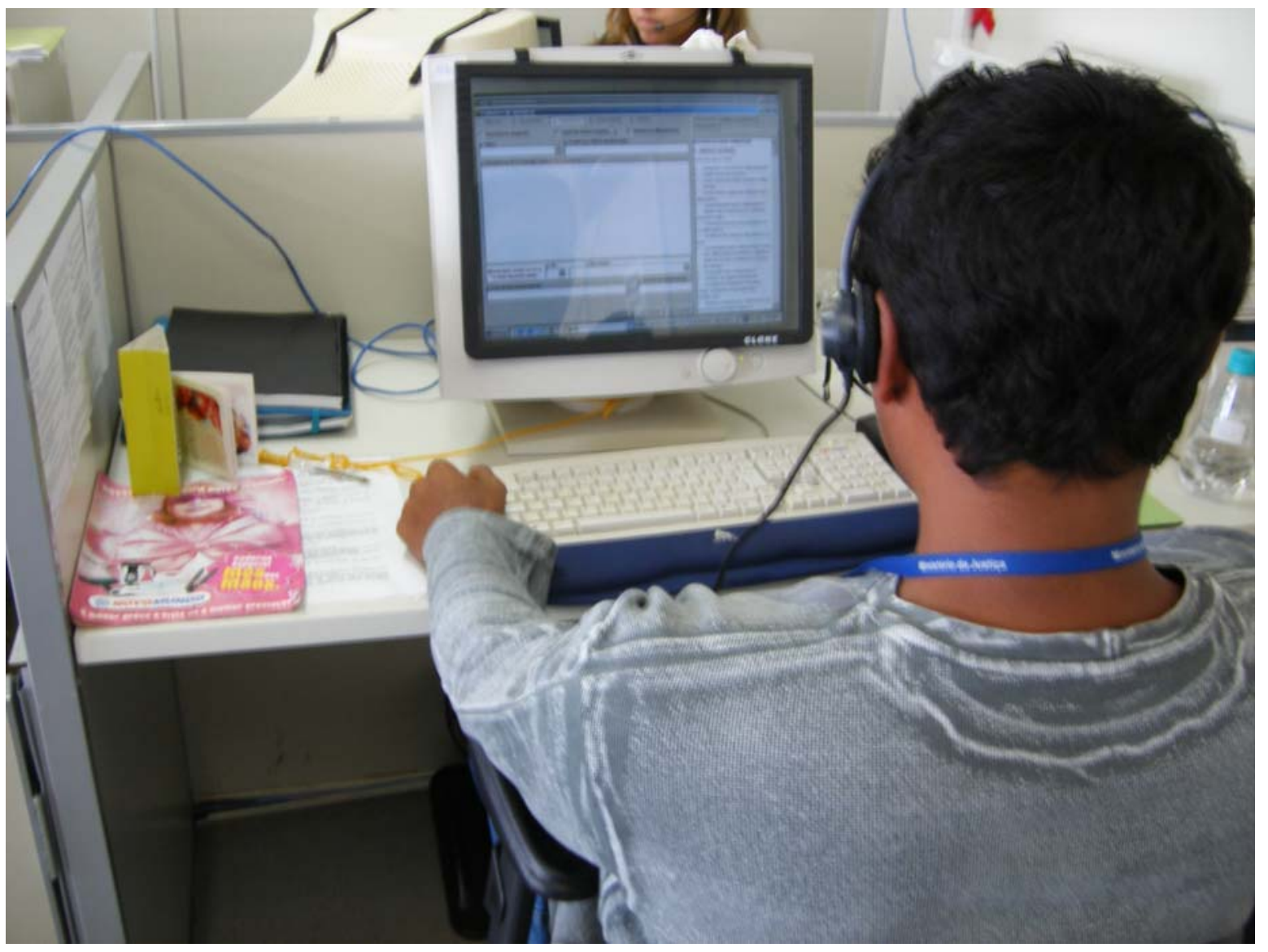

